\title{
A Review: Inflammatory Process in Alzheimer's Disease, Role of Cytokines
}

\author{
Jose Miguel Rubio-Perez and Juana Maria Morillas-Ruiz \\ Department of Food and Nutrition Technology, St. Anthony Catholic University, Campus de Los Jerónimos, s/n Guadalupe, \\ 30107 Murcia, Spain \\ Correspondence should be addressed to Juana Maria Morillas-Ruiz,jmmorillas@pdi.ucam.edu
}

Received 31 October 2011; Accepted 11 December 2011

Academic Editor: Toshio Kawamata

Copyright ( 92012 J. M. Rubio-Perez and J. M. Morillas-Ruiz. This is an open access article distributed under the Creative Commons Attribution License, which permits unrestricted use, distribution, and reproduction in any medium, provided the original work is properly cited.

\begin{abstract}
Alzheimer's disease (AD) is the most common neurodegenerative disorder to date. Neuropathological hallmarks are $\beta$-amyloid $(\mathrm{A} \beta)$ plaques and neurofibrillary tangles, but the inflammatory process has a fundamental role in the pathogenesis of $\mathrm{AD}$. Inflammatory components related to $\mathrm{AD}$ neuroinflammation include brain cells such as microglia and astrocytes, the complement system, as well as cytokines and chemokines. Cytokines play a key role in inflammatory and anti-inflammatory processes in AD. An important factor in the onset of inflammatory process is the overexpression of interleukin (IL)-1, which produces many reactions in a vicious circle that cause dysfunction and neuronal death. Other important cytokines in neuroinflammation are IL-6 and tumor necrosis factor (TNF)- $\alpha$. By contrast, other cytokines such as IL-1 receptor antagonist (IL-1ra), IL-4, IL-10, and transforming growth factor (TGF) $\beta$ can suppress both proinflammatory cytokine production and their action, subsequently protecting the brain. It has been observed in epidemiological studies that treatment with nonsteroidal anti-inflammatory drugs (NSAIDs) decreases the risk for developing AD. Unfortunately, clinical trials of NSAIDs in AD patients have not been very fruitful. Proinflammatory responses may be countered through polyphenols. Supplementation of these natural compounds may provide a new therapeutic line of approach to this brain disorder.
\end{abstract}

\section{Introduction}

Originally described by Alois Alzheimer in 1907 [1], AD is now the most common cause of dementia in the elderly. AD affects more than 4 million people in the United States [2]. It is estimated that 27 million people are affected worldwide [3]. As population life expectancy increases, the number of affected individuals is expected to triple by 2050 [2].

$\mathrm{AD}$ is a progressive brain disorder affecting regions of the brain that control memory and cognitive functions, gradually destroying a person's memory and ability to learn, to reason, to communicate, and to carry out daily activities.

The two major neuropathologic hallmarks of $\mathrm{AD}$ are extracellular $\mathrm{A} \beta$ plaques and intracellular neurofibrillary tangles. The production of $\mathrm{A} \beta$, a seminal event in $\mathrm{AD}$ [4], is a result of the cleavage of the amyloid precursor protein (APP), volume of which is high in AD. APP has important developmental functions in cell differentiation and possibly in the establishment of synapses $[5,6]$, but the function of APP in the adult brain is less clear. What we do know, however, is that it is expressed by neurons in response to cell injury. APP is, for example, a marker for axonal damage after head injury $[7,8]$. APP expression is markedly increased in the affected areas of the brain in temporal lobe epilepsy [9]. Neurofibrillary tangles are composed of the tau $(\tau)$ protein. In healthy neurons, $\tau$ is an integral component of microtubules, which are the internal support structures that transport nutrients, vesicles, mitochondria, and chromosomes from the cell body to the ends of the axon and backwards. In $\mathrm{AD}$, however, $\tau$ becomes hyperphosphorylated. This phosphorylation allows $\tau$ to bind together and form tangled threads [10].

Gliosis is also seen in $\mathrm{AD}$; activated astrocytes and microglia are characteristically found in abundance near neurons and plaques. Once activated, astrocytes and microglia 
produce several proinflammatory signal molecules, including cytokines, growth factors, complement molecules, chemokines, and cell adhesion molecules [11-15]. This activation is thought to result from the glial reaction to the events related to the ongoing deposition of $\mathrm{A} \beta$ [16-18].

\section{Inflammatory Process in Alzheimer's Disease}

Inflammation is a response to eliminate both the initial cause of cell injury as well as the necrotic cells and tissues resulting from the original insult. If tissue health is not restored, inflammation becomes a chronic condition that continuously erodes the surrounding tissues. In this type of inflammation, tissue injury and healing proceed simultaneously. The lateral damage normally caused tends to accumulate slowly, sometimes even asymptomatically during years. This can lead to severe tissue deterioration [19].

Brain inflammation is a pathological hallmark of $\mathrm{AD}$. However, the characteristic inflammatory features such as swelling, heat, and pain are not present in the brain, and therefore we refer here to chronic instead of acute inflammation [14]. A characteristic feature of chronic inflamed tissues is the presence of an increased number of monocytes, as well as monocyte-derived tissue macrophages, that is, microglia cells in the central nervous system (CNS) [14, 19]. Inflammation clearly occurs in pathologically vulnerable regions of the $\mathrm{AD}$ brain, with increased expression of acute phase proteins and proinflammatory cytokines which are hardly evident in the normal brain [20-23]. Microglia, astrocytes, and neurons are responsible for the inflammatory reaction.

Activated cells strongly produce inflammatory mediators such as proinflammatory cytokines, chemokines, macrophage inflammatory proteins, monocyte chemo-attractant proteins, prostaglandins, leukotrienes, thromboxanes, coagulation factors, reactive oxygen species (and other radicals), nitric oxide, complement factors, proteases, protease inhibitors, pentraxins, and C-reactive protein $[13,14,18,24$, 25].

The hypothesis is that the intractable nature of the $\mathrm{A} \beta$ plaques and tangles stimulates a chronic inflammatory reaction to clear this debris [25]. These plaques contain dystrophic neurites, activated microglia, and reactive astrocytes $[14,15,26]$. Aggregated amyloid fibrils and inflammatory mediators secreted by microglial and astrocytic cells contribute to neuronal dystrophy $[27,28]$. Chronically activated glia can, furthermore, kill adjacent neurons by releasing highly toxic products such as reactive oxygen intermediates, nitric oxide (NO), proteolytic enzymes, complementary factors, or excitatory amino acids [29]. Inflammatory mediators and a number of stress conditions, in turn, enhance APP production and the amyloidogenic processing of APP to induce amyloid- $\beta-42(\mathrm{~A} \beta-42)$ peptide production. These circumstances also inhibit the formation of soluble APP fraction that has a neuronal protective effect [30-35]. On the other hand, $\mathrm{A} \beta$ induces the expression of proinflammatory cytokines in glia cells in a vicious cycle $[18,36]$, the activation of the complement cascade [37-39], and the induction of inflammatory enzyme systems such as the inducible nitric oxide synthase (iNOS) and the cyclooxygenase enzyme (COX)-2. Several lines of evidence suggest that all of these factors can contribute to neuronal dysfunction and cell death, either alone or in concert [40-42].

2.1. Microglia. Microglia constitute around $10 \%$ of the cells in the nervous system. They represent the first line of defense against invading pathogens or other types of brain tissue injury. Under pathological situations, such as neurodegenerative disease, stroke, traumatic injury, and tumor invasion, these cells become activated, migrate, and surround damaged or dead cells, and subsequently clear cellular debris from the area. This action is similar to the one performed by phagocytic active macrophages of the peripheral immune system [43].

The current evidence points compellingly towards a central role for inflammation in $\mathrm{AD}$. This inflammation is mediated by proinflammatory cytokines and would create a chronic and self-sustaining inflammatory interaction between activated microglia and astrocytes, stressed neurons, and $\mathrm{A} \beta$ plaques.

Microglia have been suggested to be preferentially associated with certain amyloid plaque types [44]. Amyloid peptides and their precursor protein APP are potent glial activators [45, 46]. Disruption of the APP gene and its proteolytic products delay and decrease microglial activation [47]. This activation is directly dependent on the amyloid load. Treatment with $\beta$-sheet breakers peptide results in reduced brain inflammation [48].

$\mathrm{A} \beta$ is able to stimulate a nuclear factor-kappaB- (NF $\kappa \mathrm{B}-)$ dependent pathway that is required for cytokine production [49]. The subsequent activation of extracellular signalregulated kinase (ERK) and mitogen-activated protein kinase (MAPK) pathways by $\mathrm{A} \beta$ binding to the microglial cell surface induces proinflammatory gene expression and leads to the production of cytokines and chemokines [50].

In some situations, the role of microglia has been found to be beneficial, since activated microglia can reduce $\mathrm{A} \beta$ accumulation by increasing its phagocytosis, clearance, and degradation [51, 52]. Microglia can also secrete a number of soluble factors, such as the glia-derived neurotrophic factor (GDNF), which are potentially beneficial to the survival of neurons [53]. It was proposed, therefore, that microglial activation by active immunization might be a valid mechanism for clearance of senile plaques [54]. However, because a human trial of $\mathrm{A} \beta$ immunization led in some patients to meningoencephalitis, this treatment has been discontinued [55]. It was recently found that nasal vaccination in mice was able to decrease $\mathrm{A} \beta$. The extent of this reduction correlated with microglial activation, suggesting that this may be a promising approach for human $\mathrm{A} \beta$ immunization [56].

2.2. Astrocytes. Astrocytes are known to be important for $\mathrm{A} \beta$ clearance and degradation, for providing trophic support to neurons, and for forming a protective barrier between $\mathrm{A} \beta$ 
deposits and neurons [57]. The presence of large numbers of astrocytes associated with $\mathrm{A} \beta$ deposits in $\mathrm{AD}$ suggests that these lesions generate chemotactic molecules that mediate astrocyte recruitment.

Under certain conditions related to chronic stress, however, the role of astrocytes may not be beneficial. A report suggests that astrocytes could also be a source for $A \beta$, because they overexpress $\beta$-secretase of APP (BACE1) in response to chronic stress [57]. In vitro and in vivo experiments suggest though that inflammatory active astrocytes do not generate significant amounts of these molecules.

2.3. Complement System. The complement system represents a complex and tightly regulated attack system designed to destroy invaders and to assist in the phagocytosis of waste materials. The components of this system carry out four major functions: recognition, opsonization, inflammatory stimulation, and direct killing through the membrane attack complex [58]. Complement proteins interact with cell surface receptors to promote a local inflammatory response that contributes to the protection and healing of the host. Complement activation causes inflammation and cell damage, yet it is essential for eliminating cell debris and potentially toxic protein aggregates [59].

The complement system consists of some 30 fluidphase and cell-membrane-associated proteins that can be activated by different routes. The classical pathway (involving $\mathrm{C} 1 \mathrm{q}, \mathrm{C} 1 \mathrm{r}, \mathrm{C} 1 \mathrm{~s}, \mathrm{C} 4, \mathrm{C} 2$, and C3 components) is activated primarily by the interaction of $\mathrm{Clq}$ with immune complexes (antibody antigen), but activation can also be achieved after interaction of $\mathrm{Clq}$ with nonimmune molecules such as DNA, RNA, C-reactive protein, serum amyloid P, bacterial lipopolysaccharides, and some fungal and virus membranes. The initiation of the alternative pathway (involving C3, factor $\mathrm{B}$, factor $\mathrm{D}$, and properdin) does not require the presence of immune complexes and leads to the deposition of C3 fragments on target cells. The molecular network of classical and alternative complement cascades with pattern recognition, proteolytic activation, functions of fragments in phagocytosis, and stimulation of the host immune defense has been reviewed in detail elsewhere [6062].

Many complement proteins and receptors can be synthesized locally in the brain [63-66]. The complement system activation has been observed in brain in different inflammatory and degenerative diseases, for example, $\mathrm{AD}$, multiple sclerosis, and stroke $[59,65,67]$. Surprisingly, the most potent complement defense in human brain seems to be located on the astrocytes which can express all the components of classical and alternative pathways, such as C1-C9, regulatory factors B, D, H, I, and several complement receptors, for example, $\mathrm{C} 1 \mathrm{qR}, \mathrm{C} 3 \mathrm{aR}$ and $\mathrm{C} 5 \mathrm{aR}[63,65]$. Microglial cells exhibit a more narrow set of complement proteins, for example, C1q, C3 and receptors C1qR, CR3, and $\mathrm{C} 5 \mathrm{aR}$, which support the phagocytic uptake of targeted structures. Interestingly, neurons also express several regulatory proteins, such as factors $\mathrm{H}$ and $\mathrm{S}$, as well as receptors $\mathrm{C} 1 \mathrm{qR}, \mathrm{C} 3 \mathrm{aR}$ and C5aR $[65,66,68,69]$.
Several research articles have reported that the complement system of brain is activated in $\mathrm{AD}[59,67,70$, 71]; furthermore, this system seems to be activated at a very early stage of the disease. $A \beta$ peptides can activate the complement cascade without the presence of antibody. They can additionally produce complement components [72]. C1q protein is mainly localized in neurons, along with neuritic plaques, both in the frontal cortex and in the hippocampus [73]. Interestingly, C1q protein is present only in thioflavin-positive amyloid plaques containing the $\beta$-sheet conformation [73] showing that C1q may affect the amyloid aggregation process.

Moreover, there is an extensive literature demonstrating that the complement system also has a neuroprotective role in neuroinflammation $[59,60,71,74]$. For example, inhibition of the complement system could clearly increase amyloid plaque formation and the neurodegeneration occurring in transgenic $\mathrm{AD}$ mice [75]. Complement $\mathrm{C} 3$ knockout also aggravated the neuropathology in $\mathrm{AD}$ mice [76]. The activity of C1q protein in the clearance of apoptotic cells and $\mathrm{A} \beta$ aggregates into glial cells may well be the main cause for neuroprotection.

2.4. Chemokines. Recent experiments have focused on understanding the role of chemokines and their receptors for $\mathrm{AD}$ neuroinflammation.

The chemokine family consists of over 50 different molecules that confer chemotaxis, tissue extravasation, and modulation of leukocyte function during inflammation [77, 78]. The importance of chemokine generation in $\mathrm{AD}$ brain is underscored by the fact that these molecules may be strong regulators of microglial migration and recruitment of astrocytes to the area of neuroinflammation. They are therefore responsible for the extent of local inflammation.

While it has been reported that chemokines exert physiological action in the healthy brain [79], the majority of studies have focused on the expression pattern of chemokines and their respective receptors in neurological diseases such as multiple sclerosis, traumatic brain injury, and stroke. All of these disorders share the disruption of the blood-brain barrier as an important pathogenetic event subsequently allowing peripheral leukocytes to infiltrate the lesion site [80]. In contrast, no convincing evidence exists for bloodbrain barrier disruption or significant leukocyte infiltration in the $\mathrm{AD}$ brain.

However, several chemokines and chemokine receptors have been found to be upregulated in the AD brain [81]. Chemokines may play an important role for recruiting microglia and astroglia to the site of $\mathrm{A} \beta$ deposition. $\mathrm{A} \beta$ stimulated human monocytes generate chemokines such as IL-8, monocyte chemoattractant protein- (MCP)-1, macrophage inflammatory protein- (MIP)- $1 \alpha$ and MIP- $1 \beta$ in vitro, and microglia cultured from rapid autopsies of $\mathrm{AD}$ and nondemented patients reveal an increased expression of IL-8, MCP-1, and MIP- $1 \alpha$ after experimental exposure to A $\beta$. Supporting the hypothesis that astrocytes actively contribute to the inflammatory disease component, MIP- $1 \alpha$ has been detected in reactive astrocytes nearby $\mathrm{A} \beta$ plaques. 
2.5. Neurons. While neurons were traditionally believed to be passive bystanders in neuroinflammation, more recent evidence suggests that neurons can generate inflammatory molecules. Thus, neurons can serve as source of complement, COX-2-derived prostanoids [82-84], several cytokines [8593], and macrophage colony-stimulating factor (MCSF) [94].

Although COX-2 expression is driven by physiological synaptic activity [93] and therefore may be regarded as physiologically expressed protein in a subclass of neurons, inflammation induced by the generation of prostanoids may well contribute to neuronal destruction. As a further factor, expression of the inflammatory-induced enzyme iNOS has been described in degenerating neurons in AD brains [9597]. Compelling evidence exists also for iNOS-related longterm NO release and NO-dependent peroxynitrite formation [98]. Glial- and neuronal-derived NO and peroxynitrite have been demonstrated to cause neuronal dysfunction and cell death in vitro and in vivo $[99,100]$.

2.6. Cytokines. Cytokines are small and nonstructural proteins with molecular weights ranging from 8,000 to 40,000 Da. Originally called lymphokines and monokines to indicate their cellular sources, it soon became clear that the term "cytokine" was the best description, since nearly all nucleated cells are capable of synthesizing these proteins and, in turn, they are also capable of responding to these molecules. There is no amino acid sequence motif or threedimensional structure that links cytokines. Their biological activities allow us in turn to group them into different classes.

Cytokines are secreted by a variety of immune cells (e.g., T-lymphocytes, macrophages, natural killer cells) and nonimmune cells (e.g., Schwann cells, fibroblasts). The biological effects induced by cytokines include the stimulation or inhibition of cell proliferation, cytotoxicity/apoptosis, antiviral activity, cell growth and differentiation, inflammatory responses, and upregulation of expression of surface membrane proteins. The main function of cytokines is the regulation of T-cell differentiation from undifferentiated cells to $\mathrm{T}$-helper 1 and 2, regulatory $\mathrm{T}$ cells, and T-helper 17 cells [101]. These regulatory proteins include ILs, interferons (IFNs), colony stimulating factors (CSFs), TNFs, and certain growth factors (GFs) [102, 103].

Many of these cytokines have already been shown to be produced by neurons or glia and there are a number of reports indicating changes in their levels in $\mathrm{AD}$ brain, blood, and cerebrospinal fluid (CF). Levels of IL- $1 \alpha$, IL- $1 \beta$, IL-6, TNF- $\alpha$, granulocyte-macrophage colony-stimulating factor (GMSF), IFN- $\alpha$, the type B of IL- 8 receptor (IL-8RB), and the receptor for CSF-1 are reportedly increased in AD brain tissue $[104,105]$.

A number of interactions between cytokines and components of the $\mathrm{AD}$ senile plaques have been reported suggesting that a vicious circle might be generated [105]. Thus, the $\mathrm{A} \beta$ protein of the plaques is said to potentiate the secretion of IL- 6 and IL- 8 by IL- $1 \beta$-activated astrocytoma cells, of IL- 6 and TNF- $\alpha$ by lipopolysaccharide- (LPS-) stimulated astrocytes [106], and of IL- 8 by monocytes. Cytokines can also stimulate secretion of a number of the other proteins found in senile plaques [105]. Moreover, synergistic effects may also occur between cytokines and $\mathrm{A} \beta$. For example, IFN$\gamma$ is said to synergize with $\mathrm{A} \beta$ to cause the release of TNF- $\alpha$ and reactive nitrogen species that are toxic to neurons, and IL- 1 is reported to increase the toxicity of $\mathrm{A} \beta$ in PC12 cells.

Some cytokines clearly promote inflammation and are called proinflammatory cytokines, whereas other cytokines suppress the activity of proinflammatory cytokines and are called anti-inflammatory cytokines. For example, IL-4, IL-10, and IL-13 are potent activators of B lymphocytes; however, IL-4, IL-10, and IL-13 are also potent antiinflammatory agents. These are anti-inflammatory cytokines by virtue of their ability to suppress genes for proinflammatory cytokines such as IL-1, TNF, and the chemokines. IFN$\gamma$ is another example of the pleiotropic nature of cytokines. IFN- $\gamma$ possesses antiviral activity, in the same way as IFN$\alpha$ and IFN- $\beta$. IFN- $\gamma$ is also an activator of the pathway affecting cytotoxic T cells; however, IFN- $\gamma$ is considered a proinflammatory cytokine because it increases TNF activity and induces NO. The concept that some cytokines function would primarily be to induce inflammation while other cytokines primary function would be to suppress inflammation is fundamental to cytokine biology and also to clinical medicine.

The concept is based on the genes coding for the synthesis of small mediator molecules that are upregulated during inflammation. Therefore, a "balance" between the effects of proinflammatory and anti-inflammatory cytokines is thought to determine the outcome of disease, whether in the short term or long term. In fact, data from some studies suggest that susceptibility to disease is genetically determined by the balance or expression of either proinflammatory or anti-inflammatory cytokines. It should be considered though that some gene linkage studies are often difficult to interpret.

2.6.1. Major Proinflammatory Cytokines. The cytokine class of inflammatory mediators is secreted by microglia and astrocytes surrounding $A \beta$ neuritic plaques. Their production is increased in inflammatory states and they function by regulating the intensity and duration of the immune response [13]. The IL-1 family of cytokines includes two agonist proteins, IL- $1 \alpha$ and IL- $1 \beta$, which trigger cell activation upon binding with specific membrane receptors. Also included is IL-1ra, which is a glycosylated secretory protein of $23 \mathrm{kDa}$ that counteracts the action of IL-1 [107].

IL-1 is an important initiator of the immune response, playing a key role in the onset and development of a complex hormonal and cellular inflammatory cascade. Elevated IL$1 \beta$ has been detected in the CF and brain parenchyma within the early hours after brain injury in both humans and rodents [108, 109]. Nonetheless, IL-1 has been documented to play a role in neuronal degeneration. In astrocytes, IL-1 induces IL-6 production, stimulates iNOS activity [110], and induces the production of MCSF. In addition, IL-1 enhances neuronal acetylcholinesterase activity, microglial activation and additional IL-1 production, astrocyte activation, and expression of the beta-subunit of $\mathrm{S} 100$ protein $(\mathrm{S} 100 \beta)$ by 
astrocytes, thereby establishing a self-propagating cycle [18, $111]$.

IL-6 is a multifunctional cytokine that plays an important role in host defense [112], with major regulatory effects upon the inflammatory response [113]. IL-6 belongs to the neuropoietin family of cytokines [114], and it has both direct and indirect neurotrophic effects on neurons [115]. IL-6 promotes astrogliosis [116], activates microglia [117], and stimulates the production of acute phase proteins [118].

TNF- $\alpha$ plays a central role in initiating and regulating the cytokine cascade during an inflammatory response. It is produced as a membrane-bound precursor molecule of $26 \mathrm{kDa}$ that is cleaved by the TNF- $\alpha$ converting enzyme to produce a $17 \mathrm{kDa}$ active cytokine [119]. The levels of TNF$\alpha$ expression in the healthy brain are low, making it difficult to determine its precise role under physiological conditions. In inflammatory or disease states, TNF- $\alpha$ along with several other proinflammatory mediators and neurotoxic substances are predominantly produced by activated microglia. Neuronal production of TNF- $\alpha$ has been demonstrated [86], although brain-derived TNF- $\alpha$ is mostly synthesized by glial cells in response to pathological stimuli. Glial cells secrete both TNF- $\alpha$ and IL-1, which in turn, activate these cells in an autocrine manner to induce further cytokine production and astrogliosis. TNF- $\alpha$, on the other hand, has been reported to have neuroprotective properties [14] in the AD brain.

In addition to the general role of cytokines, $\mathrm{AD}$-specific interactions of certain cytokines and chemokines with $\mathrm{A} \beta$ may be pathophysiologically relevant. For example, IL-1 can regulate APP processing and $\mathrm{A} \beta$ production in vitro [120]. In turn, fibrillar $A \beta$ has been reported to increase neurotoxic secretory products, proinflammatory cytokines, and reactive oxygen species [121-123]. Cultured rat cortical glia exhibit elevated IL-6 mRNA after exposure to the carboxy-terminal 105 amino acids of APP [124]. In the same situation, IL-1, IL6 , TNF- $\alpha$, MIP- $1 \alpha$ and MCP- 1 increase in a dose-dependent manner after cultured microglia are incubated with $\mathrm{A} \beta$. The production of interleukins, other cytokines, and chemokines may also lead to microglial activation, astrogliosis, and further secretion of proinflammatory molecules and amyloid, thus perpetuating the cascade [50].

2.6.2. Major Anti-Inflammatory Cytokines. A second general category of cytokine action is manifested by antiinflammatory cytokines such as IL-1ra, IL-4, IL-10, and TGF$\beta$. These inhibitory cytokines can suppress proinflammatory cytokine production and action, an effect that is critical to the concept of balance among pro- and anti-inflammatory cytokines. The clinical consequence of a CNS disregulation in this balance (high levels of proinflammatory cytokines, low levels or activity of anti-inflammatory cytokines) can lead to cytokine production and synergistic cytokine actions and can induce an amplification cycle of cellular activation and cytotoxicity [125]. Thus, both cytokine-cytokine interactions and cytokine interactions with existing $\mathrm{AD}$ pathology may play critical roles in $\mathrm{AD}$ neuroinflammation.

IL-1ra is a 152 -amino-acid protein that functions as a specific inhibitor of the two other functional members of the
IL- 1 family, IL- $1 \alpha$ and IL- $1 \beta[126,127]$. IL- 1 ra is produced by monocytes and macrophages and is released into the systemic circulation, blocking the action of IL- $1 \alpha$ and IL$1 \beta$ functional ligands by competitive inhibition at the IL1 receptor level. IL-1ra binds with equal or greater affinity than does IL- $1 \alpha$ and IL- $1 \beta$ to the type $1(80 \mathrm{kDa})$ membranebound IL-1 receptor. In contrast, IL-1ra does not bind with high affinity to the type II (68 kDa) IL-1 receptor $[128,129]$.

The biological actions of IL-1 $\beta$ are regulated in vivo by IL-1ra [130]. This action is performed by preventing the binding of IL- $1 \beta$ to IL- 1 type I receptor (IL-1RI) [131]. In vitro, IL-1ra suppresses IL- $1 \beta$-induced TNF- $\alpha$ production and iNOS expression in astrocytes [132]. IL-1ra also protects against IL-1 $\beta$ neurotoxicity [133]. Furthermore, in vivo IL1ra attenuates ischaemic and excitotoxic neuronal damage [134].

IL-4 is a $20-\mathrm{kDa}$ glycoprotein produced by mature Th2 cells and cells from the mast cell or basophil lineage, which is able to influence Th-cell differentiation. IL-4 drives Th2 responses, mediates the recruitment and activation of mast cells, and stimulates the production of IgE antibodies via the differentiation of B cells into IgE-secreting cells $[135,136]$. Also, IL-4 has marked inhibitory effects on the expression and release of the proinflammatory cytokines, it is able to block or suppress the monocyte-derived cytokines, including IL-1, TNF- $\alpha$, IL-6, IL-8, and MIP- $1 \alpha[135,136]$, and it stimulates the synthesis of IL-1ra [137]. Other mechanism by which IL-4 exerts its neuroprotective effect might be related to the inhibition of IFN- $\gamma$ and the consequent decrease in the concentration of TNF- $\alpha$ and NO [138].

IL-10 is one of the main anti-inflammatory cytokines. IL-10 mRNA is detectable in the frontal and parietal lobe of the normal brain [139] and has been suggested to play an important role in neuronal homeostasis and cell survival [140]. IL-10 mediates on cells by interacting with specific cell surface receptors (IL-10Rs), present on all the major glial cell populations in the brain [140], and it limits inflammation by reducing the synthesis of proinflammatory cytokines such as IL- 1 and TNF- $\alpha$, by suppressing cytokine receptor expression and by inhibiting receptor activation in the brain. $A \beta$ does not seem to stimulate IL- 10 production by glial cells in vitro [141], but preexposure of glial cells to IL-10 inhibits $A \beta$ or LPS-induced production of proinflammatory cytokines [139], suggesting that IL-10 receptors are present in cultured glial cells [142]. IL-10 inhibits monocyte/macrophagederived TNF- $\alpha$, IL-1, IL-6, IL- 8 , IL-12, GMSF, MIP- $1 \alpha$, and MIP-2 $\alpha$ [143-145]. In addition to these activities, IL-10 attenuates surface expression of TNF receptors and promotes the shedding of TNF receptors into the systemic circulation $[146,147]$.

TGF- $\beta$ is synthesized as an inactive precursor and requires activation before exerting its effect [148]. The active molecule is a $25-\mathrm{kDa}$ homodimer of two $12.5-\mathrm{kDa}$ disulfide-linked monomers and it belongs to a superfamily of $>20$ distinct dimeric proteins that share a similar structure [149]. TGF- $\beta$ is an important regulator of cell proliferation, differentiation, and formulation of the extracellular matrix [150]. TGF- $\beta$ is capable of converting an active site of inflammation into one dominated by reparations [150]. In 
addition, TGF- $\beta$ suppresses the proliferation and differentiation of T cells and B cells and limits IL-2, IFN- $\gamma$, and TNF production.

All three known mammalian isoforms of $\mathrm{TGF}-\beta$, that is, TGF- $\beta 1,2$, and 3, are expressed in the CNS and have been implicated in the pathogenesis of $\mathrm{AD}$. TGF- $\beta$ has been shown to modulate a wide range of processes that are implicated in $\mathrm{AD}$, including brain injury response and astrocytosis, brain inflammatory response and microglial activation, extracellular matrix production, accumulation and regional distribution of amyloid, regulation of known or potential AD risk factors (e.g., APP, COX-2), and inhibition of cell death. For example, AD TGF- $\beta 1$ has been detected in plaques [151], and higher TGF- $\beta 1$ levels were found in cerebrospinal fluid [152] and serum [153] of AD cases than in nondemented controls. Immunostaining for TGF- $\beta 2$ was observed in reactive astrocytes, ramified microglia, and a portion of tangle-bearing neurons in AD cases [154]. Finally, it should be noted that immunoreactivities for TGF- $\beta 1$ and 2 receptors were higher in reactive glia in $\mathrm{AD}$ cases than in the nondemented controls [155].

2.7. Growth Factors. Growth factors are proteins, which support the survival of cells of the central and peripheral nervous system. Growth factors play a role in the development of the brain, they stimulate axonal growth and regulate the growth of different kinds of cells in the brain and periphery. In many cases, the same growth factor and corresponding receptor signalling system may thus serve a number of different functions in the body.

Nerve growth factor (NGF) is the most potent growth factor able to counteract cell death of cholinergic neurons in vitro and in vivo [156]. Increased NGF has been found in the CF of AD patients [157-159]. In spite of the fact that NGF disfunction has been suggested in the development of $\mathrm{AD}$, NGF knockout mice have not shown clear cognitive deficits. NGF has been considered, nevertheless, as a candidate for treating $\mathrm{AD}$ purified NGF, in fact, it was infused in some AD patients [160]. NGF is upregulated in brains [161] and CSF [158] of AD patients, while the high-affinity NGF receptor trkA is downregulated [162]. Interestingly, the increase of $\mathrm{NGF}$ was specific for $\mathrm{AD}$ compared to healthy controls and was dependent on the extent of neurodegeneration as expressed by the phosphotau181/A $\beta-42$ ratio [157]. Although NGF data alone did not reveal a significant difference, the comparison of NGF in $\mathrm{AD}$ patients having a phospho-tau181/A $\beta-42$ ratio $>10$ with healthy control subjects $($ ratio $<6$ ) revealed a significant difference [157]. This might suggest that NGF accumulates in neurodegeneration only at a certain stage of the disease.

Furthermore, vascular endothelial growth factor (VEGF) is an important growth factor, which regulates angiogenesis in the nervous system, and it is increased [163, 164] in $\mathrm{AD}$, resulting in enhanced microvascular density when developing the disease. The disregulation of other growth factors may also contribute to AD. For example, plateletderived growth factor (PDGF), which is mitogenic for cells of mesenchymal origin, has been found to upregulate APP in the hippocampus by inducing secretases [165-167]. Insulinlike growth factor-I (IGF-I) regulates $\mathrm{A} \beta$ levels and displays protective effects against $A \beta$ toxicity $[168,169]$. Finally, members of the TGF- $\beta$ family interact with $\mathrm{A} \beta$, contributing to its toxicity or constituting a risk for cerebral $\mathrm{A} \beta$ angiopathy $[170,171]$.

\section{Anti-Inflammatory Therapy and Alzheimer's Disease}

Based on the compelling evidence that inflammatory processes are involved in the pathogenesis of $\mathrm{AD}$, research has looked into the use of anti-inflammatory drugs as a treatment option for patients with AD. Drugs such as the NSAIDs and glucocorticoid steroids have been studied to determine if they offer any benefits to $\mathrm{AD}$ patients.

3.1. NSAIDs. The NSAIDs are a family of drugs that include the salicylate, propionic acid, acetic acid, fenamate, oxicam, and the COX-2 inhibitor classes. They have analgesic, antipyretic, and anti-inflammatory properties by inhibiting the COX enzyme that catalyses the initial step in the conversion of arachidonic acid to several eicosanoids including thromboxanes, leukotrienes, and prostaglandins. Eicosanoids play major regulatory roles in cell functions including immune and inflammatory functions.

The COX enzyme is known to exist as two isoenzymes, COX-1 and COX-2, both of which occur in the brain but whose functions are not well understood. COX-1 is responsible for homeostatic production of prostanoids. COX-2 is inducible and its expression can be modified depending on the stimuli but may also have a role in the development of homeostasis [172]. With the exception of COX-2 inhibitors, all classes of NSAIDs inhibit both COX1 and COX-2 enzymes. COX-2 inhibitors, as their name implies, selectively inhibit the COX-2 enzyme.

Epidemiological evidence indicates that NSAIDs may lower the risk of developing AD [173-176]. Since patients with rheumatoid arthritis and osteoarthritis are typically treated and are exposed to NSAIDs for a long period of time, epidemiological studies have looked into the association of these diseases and AD. Many of those studies showed an inverse relationship between having arthritis (and being treated with NSAIDs) and AD [177]. A prospective population-based study has also shown a significant reduction in the risk of AD in subjects who had taken NSAIDs for a cumulative period of 24 months or more [178]. Postmortem studies have also shown the ability of NSAIDs to reduce the inflammation that is consistently seen in $\mathrm{AD}$ brain tissue [179]. A possible mode of action for the effectiveness of NSAIDs is by the blockage of COX-2 in the brain. It has been shown that COX-2 mRNA is considerably upregulated in affected areas of $\mathrm{AD}$ brain $[180,181]$, with COX-2 immunoreactivity located mainly in pyramidal neurons in the cerebral cortex and the hippocampal formation [182], suggesting the involvement of COX-2 in AD.

The NSAIDs have been shown to directly affect the production of $A \beta$ through several mechanisms. For example, 
ibuprofen, indomethacin, and sulindac sulphide were shown to decrease the $\mathrm{A} \beta-42$ peptide by up to $80 \%$ in cultured cells (effect not observed with naproxen, celecoxib, or aspirin) [183]. Since not all NSAIDs had this effect, it would seem that this effect occurs through a process that is independent of their anti-inflammatory COX activity. Treatment of mice overexpressing APP with ibuprofen resulted in a reduction of the amyloid plaque load in the cortex along with a reduction of microglial activation in the mice [184]. A study analyzing the ability of common NSAIDs and the enantiomers of flurbiprofen to lower $A \beta$ levels in neuroglioma cells and in AAP transgenic mice showed that some but not all of the NSAIDs tested lowered the $A \beta$ in cells and were able to reduce the $A \beta$ levels in the mice [185]. Neurons that were pretreated with ibuprofen showed decreased production of $A \beta$ upon exposure to the cytokine TNF- $\alpha$ as compared to untreated neurons [186]. Another study showed that neurons that were treated with COX-1 inhibitors, such as ibuprofen and acetyl salicylic acid, were more resistant to the effects of $A \beta$ than neurons that were treated by COX-2 inhibitors [187]. This study also showed a decrease in the production of prostaglandin E2 in the neurons by treatment of both COX-1 and COX-2 inhibitors.

NSAIDs may also function by activating the peroxisomal proliferators-activated receptors (PPARs), a group of nuclear hormone receptors that act to negatively inhibit the transcription of proinflammatory genes. For example, PPAR $\alpha$ agonists have been shown to inhibit IL-6, TNF- $\alpha$, and COX-2 expression in cell cultures [188]. PPAR $\gamma$ has been shown to inhibit microglial activation and a multitude of proinflammatory agents such as cytokines, NOS, and COX-2 [189].

Unfortunately, clinical trials of NSAIDs in AD patients have not been very fruitful [190]. This was especially disappointing in the case of COX-2 inhibitors. A randomized, double-blind, placebo-controlled trial assessing the effect of the COX-2 inhibitor rofecoxib and the COX-1 and COX2 inhibitor naproxen versus placebo on $\mathrm{AD}$ progression did not slow the cognitive decline of patients with mildto-moderate AD [191]. Another randomized, double-blind, placebo-controlled trial using the COX-2 inhibitor rofecoxib did not slow the decline of $\mathrm{AD}$ [192]. Specific A $\beta$-lowering NSAIDs may need to be used in future clinical trials to see if they are clinically as effective. One possible hypothesis would be for NSAIDs to help in reducing the incidence of the disease, but NSAIDs would not be as useful once the disease occurs.

3.2. Glucocorticoid Steroids. Steroids are considered to be potent anti-inflammatory agents and function by regulating the transcription of assorted inflammatory molecules, inhibiting the production of enzymes which mediate prostaglandin production. Steroids also have an effect by reducing the expression of cytokines and complement proteins that are proinflammatory [179]. It is therefore surprising to find that the epidemiological data for the effect of the use of glucocorticoid steroids in the $\mathrm{AD}$ brain show either a very weak benefit in the patient [193] or might even show a possible harmful effect [194]. While glucocorticoids were shown to inhibit $\mathrm{A} \beta$ induction of chemokines and cytokines in the CNS [195], a randomized, placebo-controlled trial was conducted to determine whether prednisone treatment slowed the rate of cognitive decline in $\mathrm{AD}$ patients. This study showed that there was no difference in cognitive decline between the treated and the control groups [196]. Indeed, total levels of the glucocorticoid cortisol in the CF and serum of $\mathrm{AD}$ patients were found to be significantly elevated when compared to nondemented control patients [197, 198], suggesting that increased levels of steroids may be associated with $\mathrm{AD}$.

\section{Flavonoids: A Natural Strategy}

A mean by which the proinflammatory responses may be counteracted, and therefore AD's severity reduced, is through a group of natural plant-derived compounds known as polyphenols; specifically those known as "flavonoids" derived from the green tea plant. Flavonoids are a large family of compounds synthesized by plants that have a common chemical structure [199].

Green tea flavonoids like epigallocatechin gallate (EGCG) appear to promote downregulation of innate immune cell functions. Putative mechanisms of flavonoid action on the innate immune system include direct free radical scavenging $[200,201]$ as well as a reduction of inflammatory cytokine production of molecules including TNF- $\alpha$, IL- $1 \beta$, and prostaglandin E2 [202]. On line with these findings, activated microglia cocultured with neuroblastoma cells were less neurotoxic in the presence of the flavonoid fisetin, suggesting that some flavonoids may act to inhibit proinflammatory innate immune responses [202, 203].

Some flavonoids, including EGCG, may modulate Tcell response by downregulating innate immune response, by stimulating the cytokines that promote Th1 immunity (e.g., TNF- $\alpha$ ) and by promoting Th2 cytokines. These effects are thought to be mediated in part through the downregulation of NFkB signaling [204-206]. EGCG inhibits TNF$\alpha$-induced production of MCP-1 from vascular endothelial cells [207]. Furthermore, EGCG also displays the ability to suppress neuron death mediated by activated microglia [208].

Although flavonoid-rich diets and flavonoid administration prevent cognitive impairment associated with inflammation in animal studies [209-211], retrospective cohort studies are inconsistent in showing an inverse association between dietary flavonoid (e.g., green tea) intake and dementia or neurodegenerative disease risk in humans [212215]. An epidemiological study of Dutch adults, for example, found that total dietary flavonoid intake was not associated with the risk of developing $\mathrm{AD}[212,213]$. This relation does not include current smokers whose risk of $\mathrm{AD}$ decreased by half for every $12 \mathrm{mg}$ increase in daily flavonoid intake. Elderly French men and women with the lowest flavonoid intakes, on the other hand, had a 50\% higher risk of developing dementia over the next 5 years than those with the highest intakes [214]. Thus, future human studies 
(ideally randomized clinical trials) will be required. These studies should involve supplementation with relatively high doses of specific purified flavanoids to shed light to the apparent inverse risk relationship with $\mathrm{AD}$ (and whether this occurs by reducing inflammation) and also to determine if such compounds are therapeutically beneficial.

\section{Conclusions}

Increasing concurrent evidence suggests that inflammation significantly contributes to the pathogenesis of $\mathrm{AD}$. The generation and secretion of proinflammatory mediators may interact at multiple levels with neurodegeneration. Thus, proinflammatory cytokines may not only contribute to neuronal death, but they might also influence classical neurodegenerative pathways such as APP processing and $\tau$ phosphorylation.

The concomitant release of anti-inflammatory mediators may partly antagonize this action ultimately leading to chronic disease. Future studies need to determine whether the course of $\mathrm{AD}$ can be influenced by anti-inflammatory treatment strategies, and clinically novel approaches to analyze early neuroinflammation in the human brain are needed to improve how to monitor and control treatment strategies that are targeting inflammatory mechanisms.

\section{Conflict of Interests}

Authors declare no competing financial interests.

\section{Acknowledgments}

Thanks to the Seneca Foundation (Regional Agency of Science and Technology of the Region of Murcia, Spain) for J. M. Rubio-Perez fellowship. Our research has been supported financially by Directorate General of Investigation, Ministry of Education and Culture of the Autonomous Community of the Region of Murcia, Spain. The authors thank Mariela Glaser for its magnificent collaboration in the revision of the text and corrections to the language.

\section{References}

[1] Alzheimer A, "Uber eine eigenartige Erkangkung der Hirnrinde (An unusual illness of the cerebral cortex)," Allgemeine Zeitschr Psychisch-Gerichtliche Medizin, vol. 64, pp. 146-148, 1907.

[2] L. E. Hebert, P. A. Scherr, J. L. Bienias, D. A. Bennett, and D. A. Evans, "Alzheimer disease in the US population: prevalence estimates using the 2000 census," Archives of Neurology, vol. 60, no. 8, pp. 1119-1122, 2003.

[3] A. Wimo, L. Jonsson, and B. Winblad, "An estimate of the worldwide prevalence and direct costs of dementia in 2003," Dementia and Geriatric Cognitive Disorders, vol. 21, no. 3, pp. 175-181, 2006.

[4] C. L. Joachim and D. J. Selkoe, "The seminal role of $\beta$ amyloid in the pathogenesis of Alzheimer disease," Alzheimer Disease and Associated Disorders, vol. 6, no. 1, pp. 7-34, 1992.
[5] J. Löffler and G. Huber, " $\beta$-Amyloid precursor protein isoforms in various rat brain regions and during brain development," Journal of Neurochemistry, vol. 59, no. 4, pp. 1316-1324, 1992.

[6] D. J. Selkoe, M. B. Podlisny, C. L. Joachim et al., " $\beta$-Amyloid precursor protein of Alzheimer disease occurs as 110- to 135-kilodalton membrane-associated proteins in neural and nonneural tissues," Proceedings of the National Academy of Sciences of the United States of America, vol. 85, no. 19, pp. 7341-7345, 1988.

[7] D. I. Graham, S. M. Gentleman, J. A. R. Nicoll et al., "Altered beta-APP metabolism after head injury and its relationship to the aetiology of Alzheimer's disease," in Mechanisms of Secondary Brain Damage in Cerebral Ischemia and Trauma, A. Baethmann, O. Kempski, N. Plesnila, and F. Staub, Eds., pp. 96-102, Springer, Vienna, Austria, 1996.

[8] S. M. Gentleman, M. J. Nash, C. J. Sweeting, D. I. Graham, and G. W. Roberts, " $\beta$-Amyloid precursor protein ( $\beta$ APP) as a marker for axonal injury after head injury," Neuroscience Letters, vol. 160, no. 2, pp. 139-144, 1993.

[9] J. G. Sheng, F. A. Boop, R. E. Mrak, and W. S. T. Griffin, "Increased neuronal $\beta$-amyloid precursor protein expression in human temporal lobe epilepsy: association with interleukin- $1 \alpha$ immunoreactivity," Journal of Neurochemistry, vol. 63, no. 5, pp. 1872-1879, 1994.

[10] H. Braak, E. Braak, and M. Strothjohann, "Abnormally phosphorylated tau protein related to the formation of neurofibrillary tangles and neuropil threads in the cerebral cortex of sheep and goat," Neuroscience Letters, vol. 171, no. 1-2, pp. 1-4, 1994

[11] W. S. T. Griffin, L. C. Stanley, C. Ling et al., "Brain interleukin 1 and S-100 immunoreactivity are elevated in Down syndrome and Alzheimer disease," Proceedings of the National Academy of Sciences of the United States of America, vol. 86, no. 19, pp. 7611-7615, 1989.

[12] P. L. McGeer, S. Itagaki, H. Tago, and E. G. McGeer, "Reactive microglia in patients with senile dementia of the Alzheimer type are positive for the histocompatibility glycoprotein HLA-DR," Neuroscience Letters, vol. 79, no. 1-2, pp. 195-200, 1987.

[13] E. E. Tuppo and H. R. Arias, "The role of inflammation in Alzheimer's disease," International Journal of Biochemistry and Cell Biology, vol. 37, no. 2, pp. 289-305, 2005.

[14] H. Akiyama, S. Barger, S. Barnum et al., "Inflammation and Alzheimer's disease," Neurobiology of Aging, vol. 21, no. 3, pp. 383-421, 2000.

[15] J. Rogers, J. Luber-Narod, S. D. Styren, and W. H. Civin, "Expression of immune system-associated antigens by cells of the human central nervous system: relationship to the pathology of Alzheimer's disease," Neurobiology of Aging, vol. 9, no. 4, pp. 339-349, 1988.

[16] M. T. Heneka and M. K. O’Banion, "Inflammatory processes in Alzheimer's disease," Journal of Neuroimmunology, vol. 184, no. 1-2, pp. 69-91, 2007.

[17] T. Wyss-Coray, "Inflammation in Alzheimer disease: driving force, bystander or beneficial response?" Nature Medicine, vol. 12, no. 9, pp. 1005-1015, 2006.

[18] W. S. T. Griffin, J. G. Sheng, M. C. Royston et al., "Glialneuronal interactions in Alzheimer's disease: the potential role of a 'cytokine cycle' in disease progression," Brain Pathology, vol. 8, no. 1, pp. 65-72, 1998.

[19] R. Mitchell and R. Cotran, "Acute and chronic inflammation," in Robbins Basic Pathology, V. Kumar, R. Cotran, and S. Robbins, Eds., Saunders, Philadelphia, Pa, USA, 2003. 
[20] W. S. T. Griffin and R. E. Mrak, "Interleukin-1 in the genesis and progression of and risk for development of neuronal degeneration in Alzheimer's disease," Journal of Leukocyte Biology, vol. 72, no. 2, pp. 233-238, 2002.

[21] M. Cacquevel, N. Lebeurrier, S. Chéenne, and D. Vivien, "Cytokines in neuroinflammation and Alzheimer's disease," Current Drug Targets, vol. 5, no. 6, pp. 529-534, 2004.

[22] R. E. Mrak and W. S. T. Griffin, "Glia and their cytokines in progression of neurodegeneration," Neurobiology of Aging, vol. 26, no. 3, pp. 349-354, 2005.

[23] C. E. Finch and T. E. Morgan, "Systemic inflammation, infection, ApoE alleles, and Alzheimer disease: a position paper," Current Alzheimer Research, vol. 4, no. 2, pp. 185-189, 2007.

[24] R. E. Mrak, J. G. Sheng, and W. S. T. Griffin, "Glial cytokines in Alzheimer's disease: review and pathogenic implications," Human Pathology, vol. 26, no. 8, pp. 816-823, 1995.

[25] T. Town, V. Nikolic, and J. Tan, "The microglial "activation" continuum: from innate to adaptive responses," Journal of Neuroinflammation, vol. 2, article 24, 2005.

[26] D. W. Dickson, J. Farlo, P. Davies, H. Crystal, P. Fuld, and S. H. C. Yen, "Alzheimer's disease. A double-labeling immunohistochemical study of senile plaques," American Journal of Pathology, vol. 132, no. 1, pp. 86-101, 1988.

[27] R. L. Nussbaum and C. E. Ellis, "Alzheimer's disease and Parkinson's disease," The New England Journal of Medicine, vol. 348, no. 14, pp. 1356-1364, 2003.

[28] M. A. Findeis, "The role of amyloid $\beta$ peptide 42 in Alzheimer's disease," Pharmacology and Therapeutics, vol. 116, no. 2, pp. 266-286, 2007.

[29] G. Halliday, S. R. Robinson, C. Shepherd, and J. Kril, "Alzheimer's disease and inflammation: a review of cellular and therapeutic mechanisms," Clinical and Experimental Pharmacology and Physiology, vol. 27, no. 1-2, pp. 1-8, 2000.

[30] R. D. Bo, N. Angeretti, E. Lucca, M. G. De Simoni, and G. Forloni, "Reciprocal control of inflammatory cytokines, IL1 and IL-6, $\beta$-amyloid production in cultures," Neuroscience Letters, vol. 188, no. 1, pp. 70-74, 1995.

[31] G. E. Ringheim, A. M. Szczepanik, W. Petko, K. L. Burgher, S. Z. Zhu, and C. C. Chao, "Enhancement of beta-amyloid precursor protein transcription and expression by the soluble interleukin-6 receptor/interleukin-6 complex," Molecular Brain Research, vol. 55, no. 1, pp. 35-44, 1998.

[32] K. Fassbender, C. Masters, and K. Beyreuther, "Alzheimer's disease: an inflammatory disease?" Neurobiology of Aging, vol. 21, no. 3, pp. 433-436, 2000.

[33] H. Misonou, M. Morishima-Kawashima, and Y. Ihara, "Oxidative stress induces intracellular accumulation of amyloid $\beta$ - protein $(\mathrm{A} \beta)$ in human neuroblastoma cells," Biochemistry, vol. 39, no. 23, pp. 6951-6959, 2000.

[34] R. M. Friedlander, "Apoptosis and caspases in neurodegenerative diseases," The New England Journal of Medicine, vol. 348, no. 14, pp. 1365-1375, 2003.

[35] C. S. Atwood, M. E. Obrenovich, T. Liu et al., "Amyloid- $\beta$ : a chameleon walking in two worlds: a review of the trophic and toxic properties of amyloid- $\beta$," Brain Research Reviews, vol. 43, no. 1, pp. 1-16, 2003.

[36] C. Lindberg, E. Hjorth, C. Post, B. Winblad, and M. Schultzberg, "Cytokine production by a human microglial cell line: effects of $\beta$ amyloid and $\alpha$-melanocyte-stimulating hormone," Neurotoxicity Research, vol. 8, no. 3-4, pp. 267276, 2005.
[37] P. S. Aisen, "Inflammation and Alzheimer's disease: mechanisms and therapeutic strategies," Gerontology, vol. 43, no. 1-2, pp. 143-149, 1997.

[38] L. S. Perlmutter, E. Barron, and H. C. Chui, "Morphologic association between microglia and senile plaque amyloid in Alzheimer's disease," Neuroscience Letters, vol. 119, no. 1, pp. 32-36, 1990.

[39] P. L. McGeer, T. Kawamata, D. G. Walker, H. Akiyama, I. Tooyama, and E. G. McGeer, "Microglia in degenerative neurological disease," Glia, vol. 7, no. 1, pp. 84-92, 1993.

[40] N. Abbas, I. Bednar, E. Mix et al., "Up-regulation of the inflammatory cytokines IFN- $\gamma$ and IL-12 and downregulation of IL-4 in cerebral cortex regions of APPSWE transgenic mice," Journal of Neuroimmunology, vol. 126, no. 1-2, pp. 50-57, 2002.

[41] P. Bezzi, M. Domercq, L. Brambilla et al., "CXCR4-activated astrocyte glutamate release via TNFa: amplification by microglia triggers neurotoxicity," Nature Neuroscience, vol. 4, no. 7, pp. 702-710, 2001.

[42] G. C. Brown and A. Bal-Price, "Inflammatory Neurodegeneration Mediated by Nitric Oxide, Glutamate, and Mitochondria," Molecular Neurobiology, vol. 27, no. 3, pp. 325-355, 2003.

[43] L. Fetler and S. Amigorena, "Brain under surveillance: the microglia patrol," Science, vol. 309, no. 5733, pp. 392-393, 2005.

[44] M. R. D’Andrea, G. M. Cole, and M. D. Ard, "The microglial phagocytic role with specific plaque types in the Alzheimer disease brain," Neurobiology of Aging, vol. 25, no. 5, pp. 675683, 2004.

[45] D. W. Dickson, S. C. Lee, L. A. Mattiace, S. H. Yen, and C. Brosnan, "Microglia and cytokines in neurological disease, with special reference to AIDS and Alzheimer's disease," Glia, vol. 7, no. 1, pp. 75-83, 1993.

[46] S. W. Barger and A. D. Harmon, "Microglial activation by alzhelmer amyloid precursor protein and modulation by apolipoprotein E," Nature, vol. 388, no. 6645, pp. 878-881, 1997.

[47] L. A. DeGiorgio, Y. Shimizu, H. S. Chun et al., "Amyloid precursor protein gene disruption attenuates degeneration of substantia nigra compacta neurons following axotomy," Brain Research, vol. 938, no. 1-2, pp. 38-44, 2002.

[48] B. Permanne, C. Adessi, G. P. Saborio et al., "Reduction of amyloid load and cerebral damage in a transgenic mouse model of Alzheimer's disease by treatment with a beta-sheet breaker peptide," The FASEB Journal, vol. 16, no. 8, pp. 860862, 2002.

[49] C. K. Combs, J. Colleen Karlo, S. C. Kao, and G. E. Landreth, " $\beta$-amyloid stimulation of microglia anti monocytes results in $\mathrm{TNF} \alpha$-dependent expression of inducible nitric oxide synthase and neuronal apoptosis," Journal of Neuroscience, vol. 21, no. 4, pp. 1179-1188, 2001.

[50] G. J. Ho, R. Drego, E. Hakimian, and E. Masliah, "Mechanisms of cell signaling and inflammation in Alzheimer's disease," Current Drug Targets: Inflammation and Allergy, vol. 4, no. 2, pp. 247-256, 2005.

[51] S. A. Frautschy, F. Yang, M. Irrizarry et al., "Microglial response to amyloid plaques in APPsw transgenic mice," American Journal of Pathology, vol. 152, no. 1, pp. 307-317, 1998.

[52] W. Q. Qiu, D. M. Walsh, Z. Ye et al., "Insulin-degrading enzyme regulates extracellular levels of amyloid $\beta$ - protein by degradation," The Journal of Biological Chemistry, vol. 273, no. 49, pp. 32730-32738, 1998. 
[53] B. Liu and J. S. Hong, "Role of microglia in inflammationmediated neurodegenerative diseases: mechanisms and strategies for therapeutic intervention," Journal of Pharmacology and Experimental Therapeutics, vol. 304, no. 1, pp. 1-7, 2003.

[54] D. S. Gelinas, K. DaSilva, D. Fenili, P. St. George, and J. McLaurin, "Immunotherapy for Alzheimer's disease," Proceedings of the National Academy of Sciences of the United States of America, vol. 101, no. 2, pp. 14657-14662, 2004.

[55] C. Holmes, D. Boche, D. Wilkinson et al., "Long-term effects of A $\beta 42$ immunisation in Alzheimer's disease: follow-up of a randomised, placebo-controlled phase I trial," The Lancet, vol. 372, no. 9634, pp. 216-223, 2008.

[56] D. Frenkel, R. Maron, D. S. Burt, and H. L. Weiner, "Nasal vaccination with a proteosome-based adjuvant and glatiramer acetate clears $\beta$-amyloid in a mouse model of Alzheimer disease," Journal of Clinical Investigation, vol. 115, no. 9, pp. 2423-2433, 2005.

[57] S. Roßner, C. Lange-Dohna, U. Zeitschel, and J. R. PerezPolo, "Alzheimer's disease $\beta$-secretase BACE1 is not a neuron-specific enzyme," Journal of Neurochemistry, vol. 92, no. 2, pp. 226-234, 2005.

[58] P. L. McGeer and E. G. McGeer, "The possible role of complement activation in Alzheimer disease," Trends in Molecular Medicine, vol. 8, no. 11, pp. 519-523, 2002.

[59] Y. Shen and S. Meri, "Yin and Yang: complement activation and regulation in Alzheimer's disease," Progress in Neurobiology, vol. 70, no. 6, pp. 463-472, 2003.

[60] S. S. Bohlson, D. A. Fraser, and A. J. Tenner, "Complement proteins $\mathrm{Clq}$ and $\mathrm{MBL}$ are pattern recognition molecules that signal immediate and long-term protective immune functions," Molecular Immunology, vol. 44, no. 1-3, pp. 3343, 2007.

[61] J. Kohl, "The role of complement in danger sensing and transmission," Immunologic Research, vol. 34, no. 2, pp. 157176, 2006.

[62] P. Gasque, "Complement: a unique innate immune sensor for danger signals," Molecular Immunology, vol. 41, no. 11, pp. 1089-1098, 2004.

[63] S. R. Barnum, "Complement biosynthesis in the central nervous system," Critical Reviews in Oral Biology and Medicine, vol. 6, no. 2, pp. 132-146, 1995.

[64] P. Gasque, M. Fontaine, and B. P. Morgan, "Complement expression in human brain: biosynthesis of terminal pathway components and regulators in human glial cells and cell lines," Journal of Immunology, vol. 154, no. 9, pp. 4726-4733, 1995.

[65] B. P. Morgan and P. Gasque, "Expression of complement in the brain: role in health and disease," Immunology Today, vol. 17, no. 10, pp. 461-466, 1996.

[66] S. Nataf, P. F. Stahel, N. Davoust, and S. R. Barnum, "Complement anaphylatoxin receptors on neurons: new tricks for old receptors?” Trends in Neurosciences, vol. 22, no. 9, pp. 397-402, 1999.

[67] D. M. Bonifati and U. Kishore, "Role of complement in neurodegeneration and neuroinflammation," Molecular Immunology, vol. 44, no. 5, pp. 999-1010, 2007.

[68] S. A. O’Barr, J. Caguioa, D. Gruol et al., "Neuronal expression of a functional receptor for the C5a complement activation fragment," Journal of Immunology, vol. 166, no. 6, pp. 41544162, 2001.

[69] M. Bénard, E. Raoult, D. Vaudry et al., "Role of complement anaphylatoxin receptors (C3aR, C5aR) in the development of the rat cerebellum," Molecular Immunology, vol. 45, no. 14, pp. 3767-3774, 2008.

[70] M. R. Emmerling, M. D. Watson, C. A. Raby, and K. Spiegel, "The role of complement in Alzheimer's disease pathology," Biochimica et Biophysica Acta, vol. 1502, no. 1, pp. 158-171, 2000.

[71] A. J. Tenner, "Complement in Alzheimer's disease: opportunities for modulating protective and pathogenic events," Neurobiology of Aging, vol. 22, no. 6, pp. 849-861, 2001.

[72] J. Rogers, N. R. Cooper, S. Webster et al., "Complement activation by $\beta$-amyloid in Alzheimer disease," Proceedings of the National Academy of Sciences of the United States of America, vol. 89, no. 21, pp. 10016-10020, 1992.

[73] A. Afagh, B. J. Cummings, D. H. Cribbs, C. W. Cotman, and A. J. Tenner, "Localization and cell association of C1q in Alzheimer's disease brain," Experimental Neurology, vol. 138, no. 1, pp. 22-32, 1996.

[74] P. Mukherjee and G. M. Pasinetti, "The role of complement anaphylatoxin $\mathrm{C} 5 \mathrm{a}$ in neurodegeneration: implications in Alzheimer's disease," Journal of Neuroimmunology, vol. 105, no. 2, pp. 124-130, 2000.

[75] M. Maier, Y. Peng, L. Jiang, T. J. Seabrook, M. C. Carroll, and C. A. Lemere, "Complement C3 deficiency leads to accelerated amyloid $\beta$ plaque deposition and neurodegeneration and modulation of the microglia/macrophage phenotype in amyloid precursor protein transgenic mice," Journal of Neuroscience, vol. 28, no. 25, pp. 6333-6341, 2008.

[76] T. Wyss-Coray, F. Yan, A. H. T. Lin et al., "Prominent neurodegeneration and increased plaque formation in complement-inhibited Alzheimer's mice," Proceedings of the National Academy of Sciences of the United States of America, vol. 99, no. 16, pp. 10837-10842, 2002.

[77] A. D. Luster, "Mechanisms of disease: ChemokinesChemotactic cytokines that mediate inflammation," The New England Journal of Medicine, vol. 338, no. 7, pp. 436-445, 1998.

[78] T. Owens, A. A. Babcock, J. M. Millward, and H. ToftHansen, "Cytokine and chemokine inter-regulation in the inflamed or injured CNS," Brain Research Reviews, vol. 48, no. 2, pp. 178-184, 2005.

[79] J. Hesselgesser and R. Horuk, "Chemokine and chemokine receptor expression in the central nervous system," Journal of NeuroVirology, vol. 5, no. 1, pp. 13-26, 1999.

[80] A. R. Glabinski and R. M. Ransohoff, "Chemokines and chemokine receptors in CNS pathology," Journal of NeuroVirology, vol. 5, no. 1, pp. 3-12, 1999.

[81] M. Xia and B. T. Hyman, "Chemokines/chemokine receptors in the central nervous system and Alzheimer's disease," Journal of NeuroVirology, vol. 5, no. 1, pp. 32-41, 1999.

[82] S. Davis and S. Laroche, "What can rodent models tell us about cognitive decline in Alzheimer's disease?" Molecular Neurobiology, vol. 27, no. 3, pp. 249-276, 2003.

[83] V. A. Pavlov and K. J. Tracey, "The cholinergic antiinflammatory pathway," Brain, Behavior, and Immunity, vol. 19, no. 6, pp. 493-499, 2005.

[84] C. Natarajan and J. J. Bright, "Peroxisome proliferatoractivated receptor-gamma agonist inhibit experimental allergic encephalomyelitis by blocking IL-12 production, IL-12 signaling and Th1 differentiation," Genes and Immunity, vol. 3, no. 2, pp. 59-70, 2002.

[85] G. I. Botchkina, M. E. Meistrell, I. L. Botchkina, and K. J. Tracey, "Expression of TNF and TNF receptors (p55 and p75) in the rat brain after focal cerebral ischemia," Molecular Medicine, vol. 3, no. 11, pp. 765-781, 1997. 
[86] C. D. Breder, M. Tsujimoto, Y. Terano, D. W. Scott, and C. B. Saper, "Distribution and characterization of tumor necrosis factor- $\alpha$-like immunoreactivity in the murine central nervous system," Journal of Comparative Neurology, vol. 337, no. 4, pp. 543-567, 1993.

[87] C. Gong, Z. Qin, A. L. Betz, X. H. Liu, and G. Y. Yang, "Cellular localization of tumor necrosis factor alpha following focal cerebral ischemia in mice," Brain Research, vol. 801, no. 1-2, pp. 1-8, 1998.

[88] P. G. Murphy, L. S. Borthwick, R. S. Johnston, G. Kuchel, and P. M. Richardson, "Nature of the retrograde signal from injured nerves that induces interleukin-6 mRNA in neurons," Journal of Neuroscience, vol. 19, no. 10, pp. 3791-3800, 1999.

[89] O. Orzyłowska, B. Oderfeld-Nowak, M. Zaremba, S. Januszewski, and M. Mossakowski, "Prolonged and concomitant induction of astroglial immunoreactivity of interleukin1beta and interleukin- 6 in the rat hippocampus after transient global ischemia," Neuroscience Letters, vol. 263, no. 1, pp. 72-76, 1999.

[90] S. Suzuki, K. Tanaka, E. Nagata, D. Ito, T. Dembo, and Y. Fukuuchi, "Cerebral neurons express interleukin-6 after transient forebrain ischemia in gerbils," Neuroscience Letters, vol. 262, no. 2, pp. 117-120, 1999.

[91] J. L. Tchelingerian, L. Vignais, and C. Jacque, "TNF $\alpha$ gene expression is induced in neurones after a hippocampal lesion," NeuroReport, vol. 5, no. 5, pp. 585-588, 1994.

[92] S. D. Yan, S. F. Yan, X. Chen et al., "Non-enzymatically glycated tau in Alzheimer's disease induces neuronal oxidant stress resulting in cytokine gene expression and release of amyloid $\beta$-peptide," Nature Medicine, vol. 1, no. 7, pp. 693699, 1995.

[93] A. Yermakova and M. K. O’Banion, “Cyclooxygenases in the central nervous system: implications for treatment of neurological disorders," Current Pharmaceutical Design, vol. 6, no. 17, pp. 1755-1776, 2000.

[94] S. D. Yan, H. Zhu, J. Fu et al., "Amyloid- $\beta$ peptide-receptor for advanced glycation endproduct interaction elicits neuronal expression of macrophage-colony stimulating factor: a proinflammatory pathway in Alzheimer disease," Proceedings of the National Academy of Sciences of the United States of America, vol. 94, no. 10, pp. 5296-5301, 1997.

[95] M. T. Heneka, H. Wiesinger, L. Dumitrescu-Ozimek, P. Riederer, D. L. Feinstein, and T. Klockgether, "Neuronal and glial coexpression of argininosuccinate synthetase and inducible nitric oxide synthase in Alzheimer disease," Journal of Neuropathology and Experimental Neurology, vol. 60, no. 9, pp. 906-916, 2001.

[96] Y. Vodovotz, M. S. Lucia, K. C. Flanders et al., "Inducible nitric oxide synthase in tangle-bearing neurons of patients with Alzheimer's disease," Journal of Experimental Medicine, vol. 184, no. 4, pp. 1425-1433, 1996.

[97] S. C. Lee, M. L. Zhao, A. Hirano, and D. W. Dickson, "Inducible nitric oxide synthase immunoreactivity in the Alzheimer disease hippocampus: association with Hirano bodies, neurofibrillary tangles, and senile plaques," Journal of Neuropathology and Experimental Neurology, vol. 58, no. 11, pp. 1163-1169, 1999.

[98] M. A. Smith, P. L. Richey Harris, L. M. Sayre, J. S. Beckman, and G. Perry, "Widespread peroxynitrite-mediated damage in Alzheimer's disease," Journal of Neuroscience, vol. 17, no. 8, pp. 2653-2657, 1997.

[99] K. M. Boje and P. K. Arora, "Microglial-produced nitric oxide and reactive nitrogen oxides mediate neuronal cell death," Brain Research, vol. 587, no. 2, pp. 250-256, 1992.
[100] M. T. Heneka, P. A. Löschmann, M. Gleichmann et al., "Induction of nitric oxide synthase and nitric oxidemediated apoptosis in neuronal PC12 cells after stimulation with tumor necrosis factor- $\alpha$ /lipopolysaccharide," Journal of Neurochemistry, vol. 71, no. 1, pp. 88-94, 1998.

[101] L. Steinman, "A brief history of TH17, the first major revision in the $\mathrm{T} \mathrm{H} 1 / \mathrm{TH} 2$ hypothesis of $\mathrm{T}$ cell-mediated tissue damage," Nature Medicine, vol. 13, no. 2, pp. 139-145, 2007.

[102] A. Meager, "Cytokines: interleukins," in Encyclopedia of Molecular Cell Biology and Molecular Medicine, R. Meyers, Ed., pp. 115-151, Wiley-VCH, Weinheim, Germany, 2004.

[103] A. Meager, "Viral inhibitors and immune response mediators: the interferons," in Encyclopedia of Molecular Cell Biology and Molecular Medicine, R. Meyers, Ed., pp. 387-421, Wiley-VCH, Weinheim, Germany, 2005.

[104] D. Walker, E. McGeer, and P. McGeer, "Involvement of inflammation and complement in Alzheimer's disease," in Clinical Neuroimmunology, J. Antel, G. Birnbaum, and H. Härtung, Eds., pp. 172-188, Blackwell Scientific, Oxford, UK, 1997.

[105] E. McGeer and P. McGeer, "Inflammatory cytokines in the CNS," CNS Drugs, vol. 7, pp. 214-287, 1997.

[106] G. Forloni, F. Mangiarotti, N. Angeretti, E. Lucca, and M. G. De Simoni, " $\beta$-amyloid fragment potentiates IL- 6 and TNF- $\alpha$ secretion by LPS in astrocytes but not in microglia," Cytokine, vol. 9, no. 10, pp. 759-762, 1997.

[107] D. Boraschi, P. Bossu, P. Ruggiero et al., "Mapping of receptor binding sites on IL-1 $\beta$ by reconstruction of IL-1ra- like domains," Journal of Immunology, vol. 155, no. 10, pp. 47194725, 1995.

[108] C. D. Winter, F. Iannotti, A. K. Pringle, C. Trikkas, G. F. Clough, and M. K. Church, "A microdialysis method for the recovery of IL-1 $\beta$, IL- 6 and nerve growth factor from human brain in vivo," Journal of Neuroscience Methods, vol. 119, no. 1, pp. 45-50, 2002.

[109] M. N. Woodroofe, G. S. Sarna, M. Wadhwa et al., "Detection of interleukin- 1 and interleukin- 6 in adult rat brain, following mechanical injury, by in vivo microdialysis: evidence of a role for microglia in cytokine production," Journal of Neuroimmunology, vol. 33, no. 3, pp. 227-236, 1991.

[110] F. Rossi and E. Bianchini, "Synergistic induction of nitric oxide by beta-amyloid and cytokines in astrocytes," Biochemical and Biophysical Research Communications, vol. 225, pp. 474-478, 1996.

[111] R. E. Mrak and W. S. T. Griffin, "Interleukin-1, neuroinflammation, and Alzheimer's disease," Neurobiology of Aging, vol. 22, no. 6, pp. 903-908, 2001.

[112] A. Hammacher, L. D. Ward, J. Weinstock, H. Treutlein, K. Yasukawa, and R. J. Simpson, "Structure-function analysis of human IL-6: identification of two distinct regions that are important for receptor binding," Protein Science, vol. 3, no. 12, pp. 2280-2293, 1994.

[113] G. Raivich, M. Bohatschek, C. U. A. Kloss, A. Werner, L. L. Jones, and G. W. Kreutzberg, "Neuroglial activation repertoire in the injured brain: graded response, molecular mechanisms and cues to physiological function," Brain Research Reviews, vol. 30, no. 1, pp. 77-105, 1999.

[114] S. J. Hopkins and N. J. Rothwell, "Cytokines and the nervous system I: expression and recognition," Trends in Neurosciences, vol. 18, no. 2, pp. 83-88, 1995.

[115] E. N. Benveniste, "Cytokine actions in the central nervous system," Cytokine and Growth Factor Reviews, vol. 9, no. 34, pp. 259-275, 1998. 
[116] K. W. Selmaj, M. Farooq, W. T. Norton, C. S. Raine, and C. F. Brosnan, "Proliferation of astrocytes in vitro in response to cytokines. A primary role for tumor necrosis factor," Journal of Immunology, vol. 144, no. 1, pp. 129-135, 1990.

[117] C. J. Heyser, E. Masliah, A. Samimi, I. L. Campbell, and L. H. Gold, "Progressive decline in avoidance learning paralleled by inflammatory neurodegeneration in transgenic mice expressing interleukin 6 in the brain," Proceedings of the National Academy of Sciences of the United States of America, vol. 94, no. 4, pp. 1500-1505, 1997.

[118] J. V. Castell, T. Andus, D. Kunz, and P. C. Heinrich, "Interleukin-6: the major regulator of acute-phase protein synthesis in man and rat," Annals of the New York Academy of Sciences, vol. 557, pp. 87-99, 1989, discussion pp. 100-101.

[119] R. T. Perry, J. S. Collins, H. Wiener, R. Acton, and R. C. P. Go, "The role of TNF and its receptors in Alzheimer's disease," Neurobiology of Aging, vol. 22, no. 6, pp. 873-883, 2001.

[120] I. Blasko, F. Marx, E. Steiner, T. Hartmann, and B. GrubeckLoebenstein, "TNF $\alpha$ plus IFN $\gamma$ induce the production of alzheimer $\beta$-amyloid peptides and decrease the secretion of APPs," FASEB Journal, vol. 13, no. 1, pp. 63-68, 1999.

[121] P. Eikelenboom, S. S. Zhan, W. A. Van Gool, and D. Allsop, "Inflammatory mechanisms in Alzheimer's disease," Trends in Pharmacological Sciences, vol. 15, no. 12, pp. 447-450, 1994.

[122] P. L. McGeer and E. G. McGeer, "The inflammatory response system of brain: implications for therapy of Alzheimer and other neurodegenerative diseases," Brain Research Reviews, vol. 21, no. 2, pp. 195-218, 1995.

[123] P. Eikelenboom and W. A. Van Gool, "Neuroinflammatory perspectives on the two faces of Al'zheimer's disease," Journal of Neural Transmission, vol. 111, no. 3, pp. 281-294, 2004.

[124] Y. Chong, "Effect of a carboxy-terminal fragment of the Alzheimer's amyloid precursor protein on expression of proinflammatory cytokines in rat glial cells," Life Sciences, vol. 61, no. 23, pp. 2323-2333, 1997.

[125] C. R. Plata-Salamán, S. E. Ilyin, and D. Gayle, "Brain cytokine mRNAs in anorectic rats bearing prostate adenocarcinoma tumor cells," American Journal of Physiology, vol. 275, no. 2, pp. R566-R573, 1998.

[126] C. A Dinarello, "Interleukin-1, interleukin-1 receptors and interleukin-1 receptor antagonist," International Reviews of Immunology, vol. 16, pp. 457-499, 1998.

[127] C. A. Dinarello, "Biologic basis for interleukin-1 in disease," Blood, vol. 87, no. 6, pp. 2095-2147, 1996.

[128] C. A. Dinarello, "Induction of interleukin-1 and interleukin1 receptor antagonist," Seminars in Oncology, vol. 24, pp. S981-S9-93, 1997.

[129] J. E. Sims, M. A. Gayle, J. L. Slack et al., "Interleukin 1 signaling occurs exclusively via the type I receptor," Proceedings of the National Academy of Sciences of the United States of America, vol. 90, no. 13, pp. 6155-6159, 1993.

[130] D. B. Carter, M. R. Deibel, C. J. Dunn et al., "Purification, cloning, expression and biological characterization of an interleukin-1 receptor antagonist protein," Nature, vol. 344, no. 6267, pp. 633-638, 1990.

[131] J. Lundkvist, A. K. Sundgren-Andersson, S. Tingsborg et al., "Acute-phase responses in transgenic mice with CNS overexpression of IL-1 receptor antagonist," American Journal of Physiology, vol. 276, pp. R644-R651, 1999.

[132] J. Liu, M. L. Zhao, C. F. Brosnan, and S. C. Lee, "Expression of type II nitric oxide synthase in primary human astrocytes and microglia: role of IL-1beta and IL-1 receptor antagonist," Journal of Immunology, vol. 157, no. 8, pp. 3569-3576, 1996.
[133] P. Thornton, E. Pinteaux, R. M. Gibson, S. M. Allan, and N. J. Rothwell, "Interleukin-1-induced neurotoxicity is mediated by glia and requires caspase activation and free radical release," Journal of Neurochemistry, vol. 98, no. 1, pp. 258266, 2006.

[134] J. K. Relton and N. J. Rothwell, “Interleukin-1 receptor antagonist inhibits ischaemic and excitotoxic neuronal damage in the rat," Brain Research Bulletin, vol. 29, no. 2, pp. 243-246, 1992.

[135] M. A. Brown and J. Hural, "Functions of IL-4 and control of its expression," Critical Reviews in Immunology, vol. 17, no. 1, pp. 1-32, 1997.

[136] P. Wang, P. Wu, M. I. Siegel, R. W. Egan, and M. M. Billah, "Interleukin (IL)-10 inhibits nuclear factor $\kappa \mathrm{B}(\mathrm{NF} \kappa \mathrm{B})$ activation in human monocytes. IL-10 and IL-4 suppress cytokine synthesis by different mechanisms," The Journal of Biological Chemistry, vol. 270, no. 16, pp. 9558-9563, 1995.

[137] P. H. Hart, G. F. Vitti, D. R. Burgess, G. A. Whitty, D. S. Piccoli, and J. A. Hamilton, "Potential antiinflammatory effects of interleukin 4: suppression of human monocyte tumor necrosis factor $\alpha$, interleukin 1, and prostagandin E2," Proceedings of the National Academy of Sciences of the United States of America, vol. 86, no. 10, pp. 3803-3807, 1989.

[138] C. C. Chao, T. W. Molitor, and S. Hu, "Neuroprotective role of IL-4 against activated microglia," Journal of Immunology, vol. 151, no. 3, pp. 1473-1481, 1993.

[139] A. M. Szczepanik, S. Funes, W. Petko, and G. E. Ringheim, "IL-4, IL-10 and IL-13 modulate A $\beta(1-42)$-induced cytokine and chemokine production in primary murine microglia and a human monocyte cell line," Journal of Neuroimmunology, vol. 113, no. 1, pp. 49-62, 2001.

[140] K. Strle, J. H. Zhou, W. H. Shen et al., "Interleukin-10 in the brain," Critical Reviews in Immunology, vol. 21, no. 5, pp. 427-449, 2001.

[141] S. Franciosi, H. B. Choi, S. U. Kim, and J. G. McLarnon, "IL-8 enhancement of amyloid-beta (Abeta 1-42)-induced expression and production of pro-inflammatory cytokines and COX-2 in cultured human microglia," Journal of Neuroimmunology, vol. 159, pp. 66-74, 2005.

[142] A. Ledeboer, J. J. P. Brevé, A. Wierinckx et al., "Expression and regulation of interleukin-10 and interleukin-10 receptor in rat astroglial and microglial cells," European Journal of Neuroscience, vol. 16, no. 7, pp. 1175-1185, 2002.

[143] C. J. P. Clarke, A. Hales, A. Hunt, and B. M. J. Foxwell, "IL-10mediated suppression of TNF- $\alpha$ production is independent of its ability to inhibit NF $\kappa \mathrm{B}$ activity," European Journal of Immunology, vol. 28, no. 5, pp. 1719-1726, 1998.

[144] C. Gerard, C. Bruyns, A. Marchant et al., "Interleukin 10 reduces the release of tumor necrosis factor and prevents lethality in experimental endotoxemia," Journal of Experimental Medicine, vol. 177, no. 2, pp. 547-550, 1993.

[145] A. Marchant, C. Bruyns, P. Vandenabeele et al., "Interleukin10 controls interferon- $\gamma$ and tumor necrosis factor production during experimental endotoxemia," European Journal of Immunology, vol. 24, no. 5, pp. 1167-1171, 1994.

[146] H. L. Dickensheets, S. L. Freeman, M. F. Smith, and R. P. Donnelly, "Interleukin-10 upregulates tumor necrosis factor receptor type-II (p75) gene expression in endotoxinstimulated human monocytes," Blood, vol. 90, no. 10, pp. 4162-4171, 1997.

[147] D. A. Joyce, D. P. Gibbons, P. Green, J. H. Steer, M. Feldmann, and F. M. Brennan, "Two inhibitors of pro-inflammatory cytokine release, interleukin-10 and interleukin-4, have contrasting effects on release of soluble p75 tumor necrosis 
factor receptor by cultured monocytes," European Journal of Immunology, vol. 24, no. 11, pp. 2699-2705, 1994.

[148] P. Norgaard, S. Hougaard, H. S. Poulsen, and M. SpangThomsen, "Transforming growth factor beta and cancer," Cancer Treatment Reviews, vol. 21, pp. 367-403, 1995.

[149] D. M. Kingsley, "The TGF- $\beta$ superfamily: new members, new receptors, and new genetic tests of function in different organisms," Genes and Development, vol. 8, no. 2, pp. 133$146,1994$.

[150] J. J. Letterio and A. B. Roberts, "TGF- $\beta$ : a critical modulator of immune cell function," Clinical Immunology and Immunopathology, vol. 84, no. 3, pp. 244-250, 1997.

[151] E. A. Van Der Wal, F. Gomez-Pinilla, and C. W. Cotman, "Transforming growth factor- $\beta 1$ is in plaques in Alzheimer and Down pathologies," NeuroReport, vol. 4, no. 1, pp. 6972, 1993.

[152] C. C. Chao, S. Hu, W. H. Frey 2nd, T. A. Ala, W. W. Tourtellotte, and P. K. Peterson, "Transforming growth factor beta in Alzheimer's disease," Clinical and Diagnostic Laboratory Immunology, vol. 1, no. 1, pp. 109-110, 1994.

[153] C. C. Chun, T. A. Ala, S. Hu et al., "Serum cytokine levels in patients with Alzheimer's disease," Clinical and Diagnostic Laboratory Immunology, vol. 1, no. 4, pp. 433-436, 1994.

[154] T. Wyss-Coray, L. Lin, D. Von Euw, E. Masliah, L. Mucke, and P. Lacombe, "Alzheimer's disease-like cerebrovascular pathology in transforming growth factor- $\beta 1$ transgenic mice and functional metabolic correlates," Annals of the New York Academy of Sciences, vol. 903, pp. 317-323, 2000.

[155] C. F. Lippa, H. Fujiwara, D. M.A. Mann et al., "Lewy bodies contain altered $\alpha$-synuclein in brains of many familial Alzheimer's disease patients with mutations in presenilin and amyloid precursor protein genes," American Journal of Pathology, vol. 153, no. 5, pp. 1365-1370, 1998.

[156] R. Levi-Montalcini, "The nerve growth factor: thirty-five years later," Bioscience Reports, vol. 7, no. 9, pp. 681-699, 1987.

[157] I. Blasko, W. Lederer, H. Oberbauer et al., "Measurement of thirteen biological markers in CSF of patients with Alzheimer's disease and other dementias," Dementia and Geriatric Cognitive Disorders, vol. 21, no. 1, pp. 9-15, 2005.

[158] C. Hock, K. Heese, F. Müller-Spahn et al., "Increased CSF levels of nerve growth factor in patients with Alzheimer's disease," Neurology, vol. 54, no. 10, pp. 2009-2011, 2000.

[159] J. Marksteiner, M. Pirchl, C. Ullrich et al., "Analysis of cerebrospinal fluid of Alzheimer patients: biomarkers and toxic properties," Pharmacology, vol. 82, no. 3, pp. 214-220, 2008.

[160] L. Olson, A. Nordberg, H. Von Holst et al., "Nerve growth factor effects $11 \mathrm{C}$-nicotine binding, blood flow, EEG, and verbal episodic memory in an Alzheimer patient. (Case report)," Journal of Neural Transmission, vol. 4, no. 1, pp. 7995, 1992.

[161] M. Fahnestock, B. Michalski, B. Xu, and M. D. Coughlin, "The precursor pro-nerve growth factor is the predominant form of nerve growth factor in brain and is increased in Alzheimer's disease," Molecular and Cellular Neuroscience, vol. 18, no. 2, pp. 210-220, 2001.

[162] E. J. Mufson, S. Y. Ma, J. Dills et al., "Loss of basal forebrain p75NTR immunoreactivity in subjects with mild cognitive impairment and Alzheimer's disease," Journal of Comparative Neurology, vol. 443, no. 2, pp. 136-153, 2002.

[163] D. Fukumura, L. Xu, Y. Chen, T. Gohongi, B. Seed, and R. K. Jain, "Hypoxia and acidosis independently up-regulate vascular endothelial growth factor transcription in brain tumors in vivo," Cancer Research, vol. 61, no. 16, pp. 60206024, 2001.

[164] E. Tarkowski, R. Issa, M. Sjögren et al., "Increased intrathecal levels of the angiogenic factors VEGF and TGF- $\beta$ in Alzheimer's disease and vascular dementia," Neurobiology of Aging, vol. 23, no. 2, pp. 237-243, 2002.

[165] D. Gianni, N. Zambrano, M. Bimonte et al., "Platelet-derived growth factor induces the $\beta$ - $\gamma$-secretase-mediated cleavage of Alzheimer's amyloid precursor protein through a Src-Racdependent pathway," The Journal of Biological Chemistry, vol. 278, no. 11, pp. 9290-9297, 2003.

[166] N. Zambrano, D. Gianni, P. Bruni, F. Passaro, F. Telese, and T. Russo, "Fe65 is not involved in the platelet-derived growth factor-induced processing of Alzheimer's amyloid precursor protein, which activates its caspase-directed cleavage," The Journal of Biological Chemistry, vol. 279, no. 16, pp. 1616116169, 2004.

[167] J. S. Lim, H. Cho, H. S. Hong, H. Kwon, I. Mook-Jung, and Y. K. Kwon, "Upregulation of amyloid precursor protein by platelet-derived growth factor in hippocampal precursor cells," NeuroReport, vol. 18, no. 12, pp. 1225-1229, 2007.

[168] E. Carro, J. L. Trejo, T. Gomez-Isla, D. LeRoith, and I. TorresAleman, "Serum insulin-like growth factor I regulates brain amyloid- $\beta$ levels," Nature Medicine, vol. 8, no. 12, pp. 13901397, 2002.

[169] D. Aguado-Llera, E. Arilla-Ferreiro, A. Campos-Barros, L. Puebla-Jiménez, and V. Barrios, "Protective effects of insulinlike growth factor-I on the somatostatinergic system in the temporal cortex of $\beta$-amyloid-treated rats," Journal of Neurochemistry, vol. 92, no. 3, pp. 607-615, 2005.

[170] Y. Hashimoto, T. Chiba, M. Yamada et al., "Transforming growth factor $\beta 2$ is a neuronal death-inducing ligand for amyloid- $\beta$ precursor protein," Molecular and Cellular Biology, vol. 25, no. 21, pp. 9304-9317, 2005.

[171] Y. Hashimoto, M. Nawa, T. Chiba, S. Aiso, I. Nishimoto, and M. Matsuoka, "Transforming growth factor $\beta 2$ autocrinally mediates neuronal cell death induced by amyloid- $\beta$," Journal of Neuroscience Research, vol. 83, no. 6, pp. 1039-1047, 2006.

[172] I. Morita, "Distinct functions of COX-1 and COX-2," Prostaglandins and Other Lipid Mediators, vol. 68-69, pp. 165-175, 2002.

[173] J. J. M. Hoozemans, R. Veerhuis, A. J. M. Rozemuller, and P. Eikelenboom, "Non-steroidal anti-inflammatory drugs and cyclooxygenase in Alzheimer's disease," Current Drug Targets, vol. 4, no. 6, pp. 461-468, 2003.

[174] B. A. In't Veid, L. J. Launer, M. M. B. Breteler, A. Hofman, and B. H. C. Stricker, "Pharmacologic agents associated with a preventive effect on Alzheimer's disease: a review of the epidemiologic evidence," Epidemiologic Reviews, vol. 24, no. 2, pp. 248-268, 2002.

[175] M. Etminan, S. Gill, and A. Samii, "Effect of non-steroidal anti-inflammatory drugs on risk of Alzheimer's disease: systematic review and meta-analysis of observational studies," British Medical Journal, vol. 327, no. 7407, pp. 128-131, 2003.

[176] G. M. Pasinetti, "From epidemiology to therapeutic trials with anti-inflammatory drugs in Alzheimer's disease: the role of NSAIDs and cyclooxygenase in $\beta$-amyloidosis and clinical dementia," Journal of Alzheimer's Disease, vol. 4, no. 5, pp. 435-445, 2002.

[177] P. P. Zandi and J. C. S. Breitner, "Do NSAIDs prevent Alzheimer's disease? And, if so, why? The epidemiological evidence," Neurobiology of Aging, vol. 22, no. 6, pp. 811-817, 2001. 
[178] B. A. in 't Veld, A. Ruitenberg, A. Hofman et al., "Nonsteroidal antiinflammatory drugs and the risk of Alzheimer's disease," The New England Journal of Medicine, vol. 345, no. 21, pp. 1515-1521, 2001.

[179] I. R. A. Mackenzie, "Postmortem studies of the effect of anti-inflammatory drugs on Alzheimer-type pathology and associated inflammation," Neurobiology of Aging, vol. 22, no. 6, pp. 819-822, 2001.

[180] L. Ho, C. Pieroni, D. Winger, D. P. Purohit, P. S. Aisen, and G. M. Pasinetti, "Regional distribution of cyclooxygenase-2 in the hippocampal formation in Alzheimer's disease," Journal of Neuroscience Research, vol. 57, no. 3, pp. 295-303, 1999.

[181] K. Yasojima, C. Schwab, E. G. McGeer, and P. L. McGeer, "Distribution of cyclooxygenase-1 and cyclooxygenase-2 mRNAs and proteins in human brain and peripheral organs," Brain Research, vol. 830, no. 2, pp. 226-236, 1999.

[182] S. Nogawa, M. Takao, S. Suzuki, K. Tanaka, A. Koto, and Y. Fukuuchi, "COX-2 expression in brains of patients with familial Alzheimer's disease," International Congress Series, vol. 1252, pp. 363-372, 2003.

[183] S. Weggen, J. L. Eriksen, P. Das et al., "A subset of NSAIDs lower amyloidogenic A $\beta 42$ independently of cyclooxygenase activity," Nature, vol. 414, no. 6860, pp. 212-216, 2001.

[184] Q. Yan, J. Zhang, H. Liu et al., "Anti-inflammatory drug therapy alters $\beta$-amyloid processing and deposition in an animal model of Alzheimer's disease," Journal of Neuroscience, vol. 23, no. 20, pp. 7504-7509, 2003.

[185] J. L. Eriksen, S. A. Sagi, T. E. Smith et al., "NSAIDs and enantiomers of flurbiprofen target $\gamma$-secretase and lower A $\beta 42$ in vivo," Journal of Clinical Investigation, vol. 112, no. 3, pp. 440-449, 2003.

[186] I. Blasko, A. Apochal, G. Boeck, T. Hartmann, B. GrubeckLoebenstein, and G. Ransmayr, "Ibuprofen decreases cytokine-induced amyloid beta production in neuronal cells," Neurobiology of Disease, vol. 8, no. 6, pp. 1094-1101, 2001.

[187] C. Bate, R. Veerhuis, P. Eikelenboom, and A. Williams, "Neurones treated with cyclo-oxygenase-1 inhibitors are resistant to amyloid-beta1-42," Neuroreport, vol. 14, no. 16, pp. 2099-2103, 2003.

[188] C. K. Combs, P. Bates, J. C. Karlo, and G. E. Landreth, "Regulation of $\beta$-amyloid stimulated proinflammatory responses by peroxisome proliferator-activated receptor $\alpha$," Neurochemistry International, vol. 39, no. 5-6, pp. 449-457, 2001.

[189] G. E. Landreth and M. T. Heneka, "Anti-inflammatory actions of peroxisome proliferator-activated receptor gamma agonists in Alzheimer's disease," Neurobiology of Aging, vol. 22, no. 6, pp. 937-944, 2001.

[190] P. S. Aisen, "The potential of anti-inflammatory drugs for the treatment of Alzheimer's disease," The Lancet Neurology, vol. 1, no. 5, pp. 279-284, 2002.

[191] P. S. Aisen, K. A. Schafer, M. Grundman et al., “. Effects of rofecoxib or naproxen vs placebo on Alzheimer disease progression: a randomized controlled trial," Journal of the American Medical Association, vol. 289, no. 21, pp. 28192826, 2003.

[192] S. A. Reines, G. A. Block, J. C. Morris et al., "No effect on Alzheimer's disease in a 1-year, randomized, blinded, controlled study," Neurology, vol. 62, no. 1, pp. 66-71, 2004.

[193] M. Hüll, K. Lieb, and B. L. Fiebich, "Pathways of inflammatory activation in Alzheimer's disease: potential targets for disease modifying drugs," Current Medicinal Chemistry, vol. 9, no. 1, pp. 83-88, 2002.
[194] M. E. Harris-White, T. Chu, S. A. Miller et al., "Estrogen (E2) and glucocorticoid (Gc) effects on microglia and $\mathrm{A} \beta$ clearance in vitro and in vivo," Neurochemistry International, vol. 39, no. 5-6, pp. 435-448, 2001.

[195] A. M. Szczepanik and G. E. Ringheim, "IL-10 and glucocorticoids inhibit $\mathrm{A} \beta(1-42)$ and lipopolysaccharide-induced pro-inflammatory cytokine and chemokine induction in the central nervous system," Journal of Alzheimer's Disease, vol. 5, no. 2, pp. 105-117, 2003.

[196] P. S. Aisen, K. L. Davis, J. D. Berg et al., "A randomized controlled trial of prednisone in Alzheimer's disease," Neurology, vol. 54, no. 3, pp. 588-593, 2000.

[197] E. Ferrari, A. Arcaini, R. Gornati et al., "Pineal and pituitaryadrenocortical function in physiological aging and in senile dementia," Experimental Gerontology, vol. 35, no. 9-10, pp. 1239-1250, 2000.

[198] E. R. Peskind, C. W. Wilkinson, E. C. Petrie, G. D. Schellenberg, and M. A. Raskind, "Increased CSF cortisol in AD is a function of APOE genotype," Neurology, vol. 56, no. 8, pp. 1094-1098, 2001.

[199] G. R. Beecher, "Overview of dietary flavonoids: nomenclature, occurrence and intake," Journal of Nutrition, vol. 133, no. 10, pp. 3248S-3254S, 2003.

[200] F. Hashimoto, M. Ono, C. Masuoka et al., "Evaluation of the anti-oxidative effect (in vitro) of tea polyphenols," Bioscience, Biotechnology and Biochemistry, vol. 67, no. 2, pp. 396-401, 2003.

[201] W. Bors and M. Saran, "Radical scavenging by flavonoid antioxidants," Free Radical Research Communications, vol. 2, no. 4-6, pp. 289-294, 1987.

[202] L. T. Zheng, J. Ock, B. M. Kwon, and K. Suk, "Suppressive effects of flavonoid fisetin on lipopolysaccharideinduced microglial activation and neurotoxicity," International Immunopharmacology, vol. 8, no. 3, pp. 484-494, 2008.

[203] J. S. Kim and C. Jobin, "The flavonoid luteolin prevents lipopolysaccharide-induced NF- $\kappa \mathrm{B}$ signalling and gene expression by blocking $\mathrm{I} \kappa \mathrm{B}$ kinase activity in intestinal epithelial cells and bone-marrow derived dendritic cells," Immunology, vol. 115, no. 3, pp. 375-387, 2005.

[204] J. Y. Kim, T. Kina, Y. Iwanaga, H. Noguchi, K. Matsumura, and S. H. Hyon, "Tea polyphenol inhibits allostimulation in mixed lymphocyte culture," Cell Transplantation, vol. 16, no. 1, pp. 75-83, 2007.

[205] H. K. Tae, H. L. Jin, K. S. Chung et al., "Epigallocatechin-3gallate enhances CD8+ T cell-mediated antitumor immunity induced by DNA vaccination," Cancer Research, vol. 67, no. 2, pp. 802-811, 2007.

[206] K. Min, W. K. Yoon, S. K. Kim, and B. H. Kim, "Immunosuppressive effect of silibinin in experimental autoimmune encephalomyelitis," Archives of Pharmacal Research, vol. 30, no. 10, pp. 1265-1272, 2007.

[207] H. Y. Ahn, Y. Xu, and S. T. Davidge, "Epigallocatechin3-O-gallate inhibits TNF $\alpha$-induced monocyte chemotactic protein-1 production from vascular endothelial cells," Life Sciences, vol. 82, no. 17-18, pp. 964-968, 2008.

[208] Z. Xu, S. Chen, X. Li, G. Luo, L. Li, and W. Le, "Neuroprotective effects of (-)-epigallocatechin-3-gallate in a transgenic mouse model of amyotrophic lateral sclerosis," Neurochemical Research, vol. 31, no. 10, pp. 1263-1269, 2006.

[209] P. Goyarzu, D. H. Malin, F. C. Lau et al., "Blueberry supplemented diet: effects on object recognition memory and nuclear factor-kappa B levels in aged rats," Nutritional Neuroscience, vol. 7, no. 2, pp. 75-83, 2004. 
[210] J. A. Joseph, N. A. Denisova, G. Arendash et al., "Blueberry supplementation enhances signaling and prevents behavioral deficits in an Alzheimer disease model," Nutritional Neuroscience, vol. 6, no. 3, pp. 153-162, 2003.

[211] D. F. Obregon, K. Rezai-Zadeh, Y. Bai et al., "ADAM10 activation is required for green tea (-)-epigallocatechin-3gallate- induced $\alpha$-secretase cleavage of amyloid precursor protein," The Journal of Biological Chemistry, vol. 281, no. 24, pp. 16419-16427, 2006.

[212] D. Laurin, K. H. Masaki, D. J. Foley, L. R. White, and L. J. Launer, "Midlife dietary intake of antioxidants and risk of late-life incident dementia: the Honolulu-Asia Aging Study," American Journal of Epidemiology, vol. 159, no. 10, pp. 959967, 2004.

[213] L. R. White, H. Petrovitch, G. W. Ross et al., "Brain aging and midlife tofu consumption," Journal of the American College of Nutrition, vol. 19, no. 2, pp. 242-255, 2000.

[214] M. J. Engelhart, M. I. Geerlings, A. Ruitenberg et al., "Dietary intake of antioxidants and risk of Alzheimer disease," Journal of the American Medical Association, vol. 287, no. 24, pp. 3223-3229, 2002.

[215] D. Commenges, V. Scotet, S. Renaud, H. Jacqmin-Gadda, P. Barberger-Gateau, and J. F. Dartigues, "Intake of flavonoids and risk of dementia," European Journal of Epidemiology, vol. 16, no. 4, pp. 357-363, 2000. 


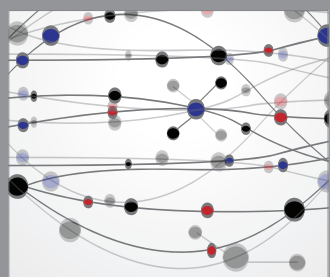

The Scientific World Journal
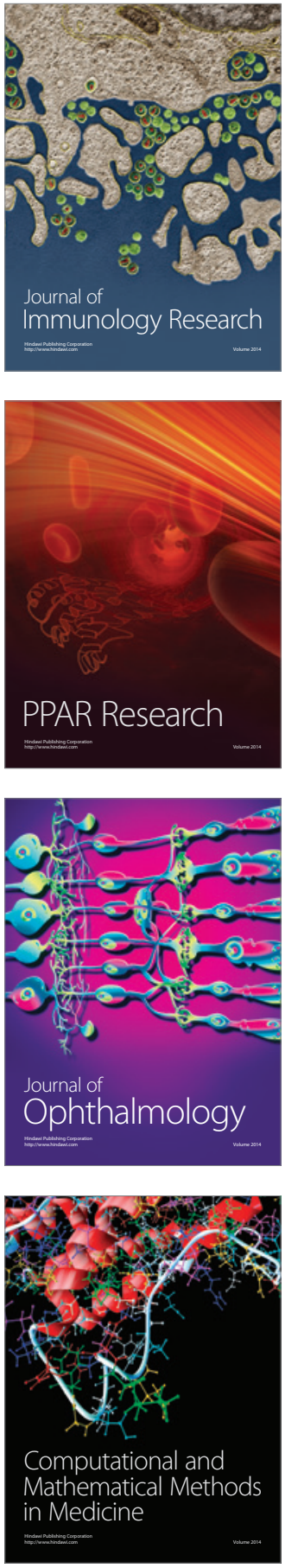

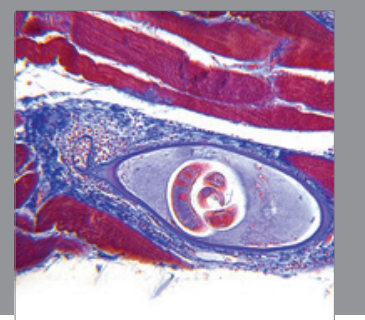

Gastroenterology

Research and Practice
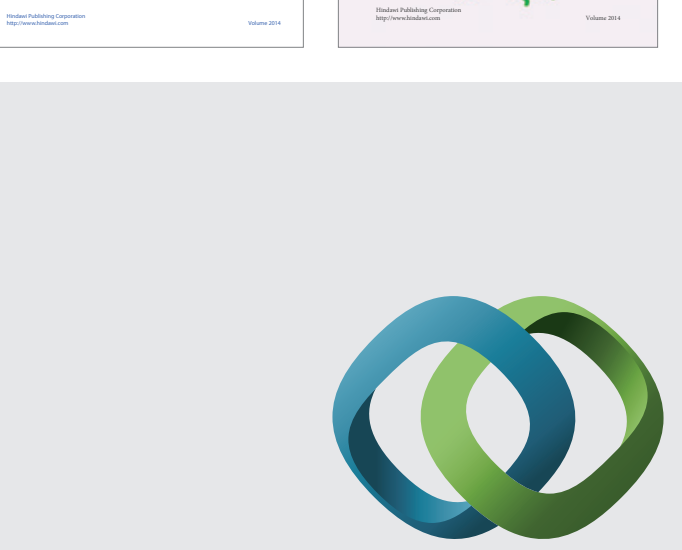

\section{Hindawi}

Submit your manuscripts at

http://www.hindawi.com
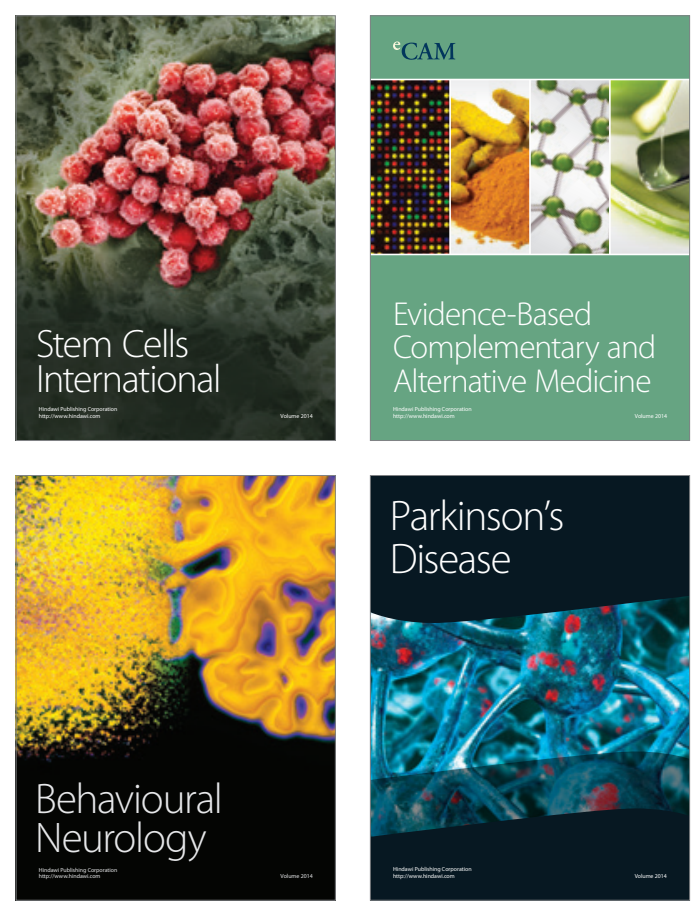

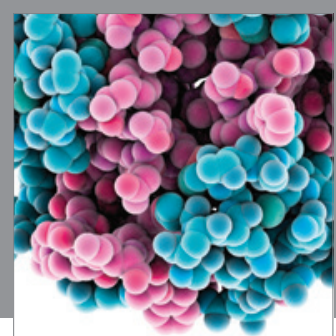

Journal of
Diabetes Research

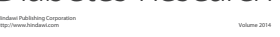

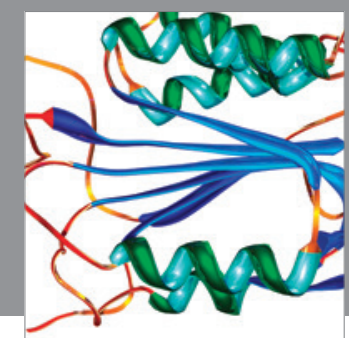

Disease Markers
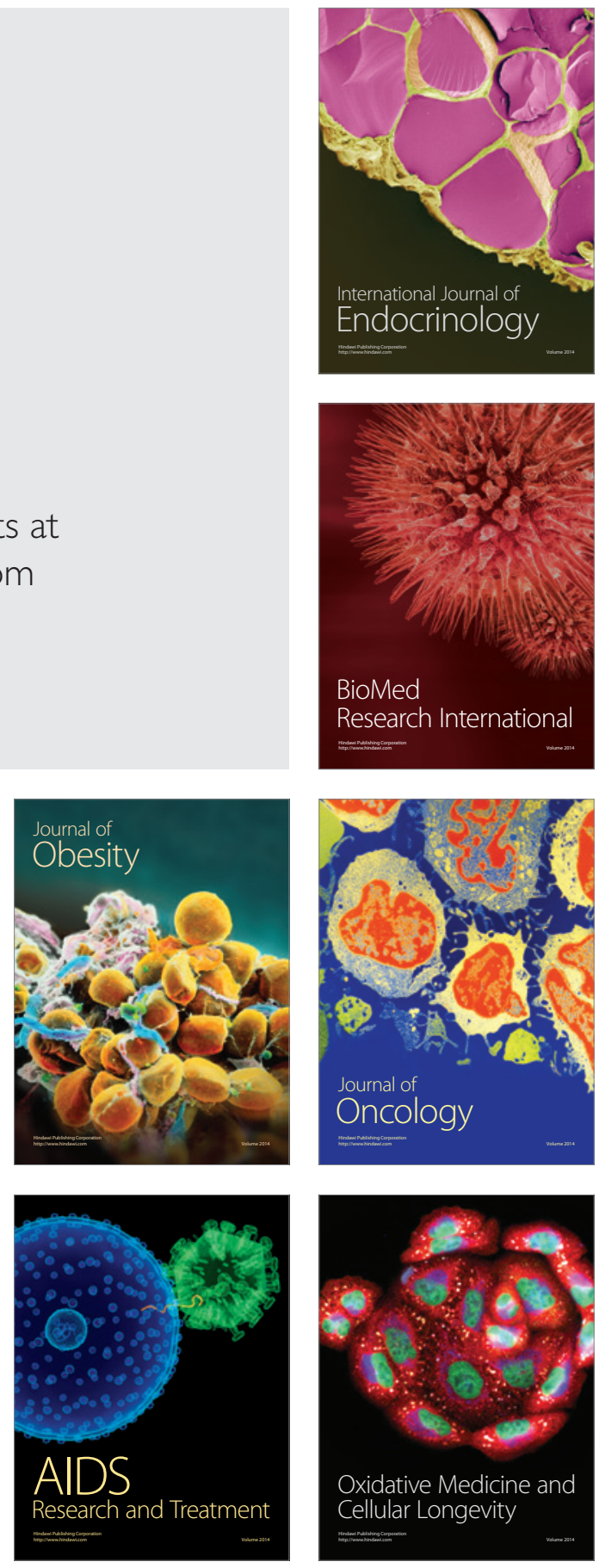